\title{
PERKEMBANGAN REGULASI RUMAH IBADAT DALAM KONTEKS NEGARA BANGSA (NKRI) PERSPEKTIF MAQASHID AL-SYARI'AH
}

\author{
Oleh \\ Sukandi \\ sukandy.arifin@gmail.com \\ Universitas Ibrahimy Situbondo, Indonesia
}

\begin{abstract}
:
The background of this research is the phenomenon that occurs in the Indonesian society that shows the gap between das sein and das sollen. Evidenced by the destruction, rejection, and burning of houses of worship. Rules should bring benefit to all people, not only to the majority. The rejection of the majority community towards the establishment of the Synagogue is a sign that there is a possibility of errors in the regulations or the community. The method used is the library method. The results of this study are the development of the houses of worship regulations can be grouped into two models. The first model is to detail or complete the previous regulations, which are in the licensing, monitoring and conflict resolution items. The second model is to bring up new regulations that did not exist in the previous regulations, namely in the presence of the religious harmony forum (FKUB) items and sources of funds, temporary houses of worship, temporary permits for building utilization, and transition mechanisms. While the second formulation produced Maqashid Al-Shari'ah's views on the development of the houses of worship regulations can be categorized into three groups. The first category is Dharuriyat, namely: the establishment of houses of worship and the formation of the religious harmony forum (FKUB). The second category is Hajiyat, the main purpose of making regulations on houses of worship is the realization of religious harmony under the auspices of the religious harmony forum (FKUB). They are: Supervision, Reporting and Resolution of conflicts. The third category is Tahsiniyat, if this regulation is not enforced it will not interfere with the realization of the main objective. This regulation is in the form of: Temporary Worship House, Temporary Permit for Building Utilization and Transition Mechanism for Worship.
\end{abstract}

Keywords: Rumah Ibadat, Negara Bangsa, Maqashid Al-Syari'ah

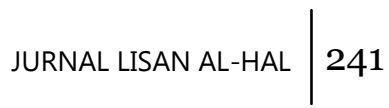




\section{A. Pendahuluan}

Indonesia sebagai negara yang sangat tinggi tingkat keragaman penduduknya pernah mewacanakan bentuk dan dasar negara yang hendak dirumuskan, setelah merdeka pada tahun 1945 para pemuka dan pendiri republik ini sepakat bahwa sistem yang akan digunakan adalah demokrasi dengan pancasila sebagai dasar dan ideologi dalam berbangsa dan bernegara. Indonesia, dengan pancasila sebagai dasarnya selalu dinyatakan sebagain bukan Islam (Daulah Islamiyyah). Tetapi dalam waktu yang sama Indonesia disebut sebagai daerah (Daulah Islam). Sebgaimana diketahui, kehadiran negara dalam pandangan Islam bukanlah tujuan, melainkan sebagai sarana untuk mencapai tujuan (washilah). Tujuannya adalah terwujudnya kemaslahatan manusia dzahirbathin, dunia-akhirat atau dengan kata lain terwujudnya kesejahteraan dan kemakmuran yang berkeadilan dan berketuhanan.

Negara menjamin kebebasan semua warga negaranya untuk melaksanakan kepercayaannya masing-masing seperti tercantum dalam UUD 1945 Pasal 29 ayat (2) yang berbunyi: "Negara menjamin kemerdekaan tiap-tiap penduduk untuk memeluk agamanya masingmasing dan untuk beribadah menurut agama dan kepercayaan itu". ${ }^{1}$ Oleh karena itu rumah ibadah dan pelaksanaan ibadah umat beragama adalah hal yang penting dan mendasar bagi setiap umat beragama yang dijamin oleh negara.

Pemerintah berusaha mewujudkan kerukunan umat beragama melalui Surat Keputusan Bersama Menteri Agama dan Menteri Dalam Negeri 1969. Kendatipun demikian, berbagai kasus intoleransi beragama dan deskriminasi seringkali terjadi antara umat beragama. Kehidupan beragama yang kurang kondusif ini menurut pemerintah disebabkan oleh peraturan yang dimaksud adalah, SKB Tahun 1969, belum mengatur secara rinci prosedur pendirian tempat ibadah.

Selama 11 kali Departemen Agama dan Departemen Dalam Negeri mengundang para wakil-wakil resmi dari masing-masing majelis agama untuk membahas dan merevisi SKB No. 1 Tahun 1969. Maka pada tanggal 21 Maret 2006 Menteri Agama dan Menteri Dalam Negeri mensahkan Peraturan Bersama Menteri Agama dan Menteri Dalam Negeri No. 9 dan 8 Tahun 2006 (PBM No. 9 dan 8 Tahun 2006) tentang Pedoman Pelaksanaan Tugas Kepala Daerah/Wakil Kepala Daerah Dalam Pemeliharaan Kerukunan Umat Beragama, Pemberdayaan Forum Kerukunan Umat Beragama (FKUB), dan Pendirian Rumah Ibadat.

\section{UUD 1945 hal.30}

$242 \mid$ JURNAL LISAN AL-HAL 
Sekalipun PBM 2 Menteri telah mengatur pendirian Rumah Ibadah, fakta membuktian di berbagai daerah di Indonesia seringkali terjadi intoleransi beragama seperti di tolikara papua pada bulan juli tahun 2015 terjadi pembakaran Masjid oleh umat Nasrani menjelang umat muslim melaksanakan Shalat Idul Fitri. Bukan hanya masjid, 6 rumah dan 11 kios juga dibakar karena umat islam ditolikara terbilang minoritas. ${ }^{2}$

Kemudian pada tanggal 13 oktober 2015 terjadi pembakaran Gereja Huriah Kristen Indonesia (GHKI) di Singkil Aceh 1 korban tewas dan 4 orang luka-luka, kejadian ini terkait bangunan Gereja tersebut tidak memiliki izin pembangunan, padahal kota serambi makkah tersebut dikenal dengan memiliki solidaritas keagamaan yang tinggi. ${ }^{3}$

Hal yang hampir serupa, sebelumnya juga sempat terjadi di daerah Bekasi Jawa Barat tanggal 15 Agustus 2015 sejumlah Ormas Islam menuntut pemerintah Kota Bekasi untuk membatalkan surat rekomendasi pembangunan Santa Clara, ribuan massa tersebut yang tergabung dalam Aliansi Majelis Silaturahim Umat Islam Bekasi menuntut dibatalkannya rencana pembangunan pembangunan Gereja Katolik Santa Clara kelurahan Harapan Baru kecamatan bekasi Utara Kota bekasi, padahal Gereja Santa Clara tersebut tidak ada cacat administrasi, namun Walikota Bekasi Rahmat Effendi sementara menghentikan pembangunan Gereja Tersebut. ${ }^{4}$

Kemudian juga terjadi gesekan antar golongan di Tanjung Balai Kota 1 kecamatan Tanjung Balai Selatan Kota, Sumatera Utara. Bermula dari seorang wanita bernama Meliana yang mendatangi Nadzir Masjid untuk menyampaikan keluhannya karena merasa terganggu suara adzan yang dikumandangkan di Masjid Jami' Al-Maksum, kejadian ini berakibat pembakaran Vihara dan 4 kelenteng yang berjarak 500 meter dari Jl karya serta 3 mobil dan 3 sepeda motor. ${ }^{5}$ Dan masih banyak intoleransi beragama yang terjadi di berbagai daerah di Indonesia tercinta ini.

Jika kita melihat sejarah Nabi Muhammad Saw, Nabi selalu memberikan penghormatan pada antar umat beragama tidak ada paksaan untuk masuk agama islam dan memberikan toleransi antar umat

\footnotetext{
2http://nasional.republika.co.id/berita/nasional/daerah/15/07/17/nrmprs-inikronologi-pembakaran-masjid-di-tolikara. Di akses tanggal 4 Maret 2020.

3 http://nasional.news.viva.co.id/news/read/686836-detik-detik-pembakarangereja-di-aceh. Di akses tanggal 4 Maret 2020.

4 http://www.beritasatu.com/megapolitan/298018-ormas-islam-bekasi-tuntutbatalkan-pembangunan-gereja-santa-clara.html diakses tanggal 4 Maret 2020.

5 http://nasional.news.viva.co.id/news/read/686836-detik-detik-pembakarangereja-di-aceh. Di akses pada tanggal 4 Maret 2020.
} 
beragama, sebagaimana Al-Qur'an menyatakan:

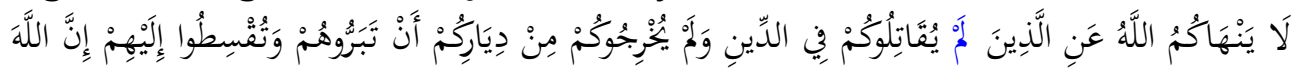

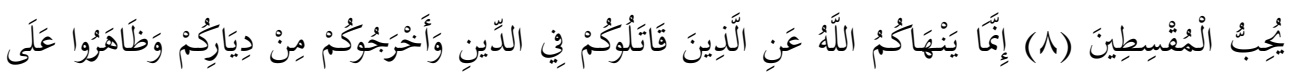

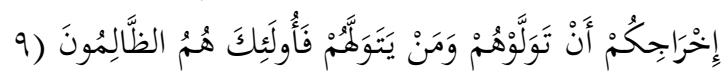

"Allah tidak melarang kamu untuk berbuat baik dan berlaku adil terhadap orang-orang yang tidak memerangimu dalam urusan agama dan tidak mengusir kamu dari kampung halamanmu. Sesungguhnya Allah mencintai orang-orang yang berlaku adil (8) Sesungguhnya Allah hanya melarang kamu menjadikan mereka sebagai kawanmu orang-orang yang memerangimu dalam urusan agama dan mengusir kamu dari kampung halamanmu, dan membantu (orang lain) untuk mengusirmu. Dan barangsiapa menjadikan mereka sebagai kawan, maka mereka itulah orang-orang yang zalim (9)". (QS : al-mumtahanah 8-9)".

Islam juga menjunjung tinggi persatuan, perpecahan adalah sesuatu yang oleh islam diperintah untuk dihindari,

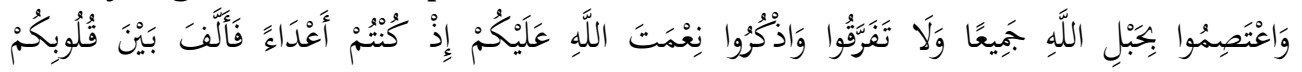

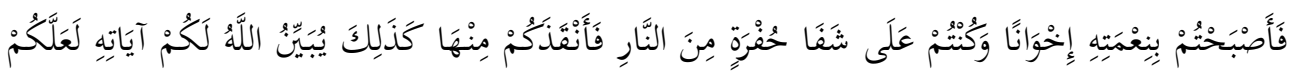

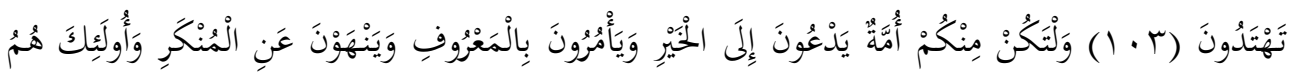

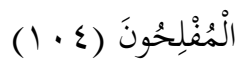

"Dan berpeganglah kamu semuanya kepada tali Allah, dan jnganlah kamu bercerai berai, dan ingatlah akan nikmat Allah kepada kamu ketika kamu dahulu (masa jahiliyah) bermusuh-musuhan, maka Allah mempersatukan hatimu, lalu menjadilah kamu karena nikmat Allah, orang-orang yang bersaudara dan kamu telah berada di tepi jurang neraka, lalu Allh menyelamatkan kamu daripadanya. Demikianlah Allah menerangkan ayatayatNya kepadamu, agar kamu mendapat petunujuk." (QS.Ali 'Imran [3]:103)

Menafsiri ayat tersebut, Musthafa al-Maghri menyatakan, bahwa agama memerintahkan seluruh lapisan masyarakat dalam satu bangsa bersatu padu meskipun di dalamnya terdapat perbedaan agama, ras, dan suku. Perintah agama agar masyarakat dalam satu bangsa menggalang persatuan ini bukan didasari oleh sikap fanatisme golongan (al-ashabiyyah al-jinsiyyah), melainkan cita-cita kuat untuk memakmurkan tanah air yang di anugerahkan Tuhan. ${ }^{6}$

\footnotetext{
${ }^{6}$ Tafsir al-Maraghi (daarul kutub ilmiyah DKI lebanon), Juz 4, 17.
} 
Upaya mewujudkan kesejahteraan masyarakat pada merupakan cita-cita dari pembangunan agama. Kesejahteraan dalam hal ini mencakup dimensi lahir batin, material dan spiritual. Lebih dari itu agama menghendaki agar pemeluknya menjalani kehidupan yang aman dan damai. Oleh karena itu pembangunan agama diharapkan dapat memberikan kontribusi nyata dalam mewujudkan Indonesia yang aman, damai, dan sejahtera. Sejalan dengan realitas kehidupan beragama yang berkembang di masyarakat dengan pengembangan nilai-nilai keagamaan serta peningkatan kerukunan umat beragama.

\section{B. Metode Penelitian}

Berdasar dari latar belakang ini diatas rumusan masalah dalam penelitian ini sebagai yaitu: pertama, bagaimana perkembangan regulasi rumah ibadat dalam konteks negara bangsa (NKRI)? Kedua, bagaimana pandangan maqashid al-syari'ah terhadap perkembangan regulasi rumah ibadat tersebut?. melengkapi rumusan masalah, tujuan dari penelitian adalah hendak mendeskripsikan perkembangan regulasi rumah ibadat dalam konteks negara bangsa (NKRI) dan mendeskripsikan pandangan maqashid al-syari'ah terhadap perkembangan regulasi rumah ibadat tersebut.

Metode penelitian yang digunakan terfokus pada kajian sejumlah teks dan data yang berkaitan dengan pendirian rumah ibadah. Penulis akan memaparkan mengenai bagaimana pendirian rumah ibadah dalam surat keputusan bersama 2 Menteri lalu memaparkan konsep pendirian rumah ibadah antara lain pengertian rumah ibadah itu sendiri, pendirian dan pengelolaannya serta perkembangan regulasinya. Pemaparan data ini berkaitan dengan kebebasan warga negara dalam memeluk agama, termasuk di dalamnya pendirian rumah ibadah. Pemerintah dalam hal ini berperan penting untuk menjamin dan mengatur masyarakat yang menjadi warga negaranya untuk mewujudkan hal tersebut.

Jenis penelitian yang dilakukan ini termasuk dalam kategori penelitian kepustakaan (library research), 7 dan apabila dipandang dari sisi paradigma penelitian, maka penelitian hukum Islam ini mengadopsi dan mengadaptasi sebagian teknik penelitian kualitatif. Penelitian kualitatif adalah prosedur penelitian yang menghasilkan data yang tidak bisa diukur

${ }^{7}$ Serangkaian kegiatan penelitian yang berkenaan dengan metode pengumpulan data pustaka, membaca, mencatat, serta mengolah bahan penelitian tanpa memerlukan terjun langsung ke lapangan melalui survei maupun observasi untuk mendapatkan data yang dicari. Lihat, Mestika Zed, Metode Penelitian Kepustakaan, (Jakarta:Yayasan Obor Indonesia, 2008), 03. 
atau dinilai dengan angka secara langsung. ${ }^{8}$

\section{Konsep Maslahat (Maqashid al-Syari'ah) Sebagai Pendekatan Teori}

\section{Pengertian Maslahat (Maqashid al-Syari'ah)}

Dilihat dari sisi etimologis, kata mashlahah merupakan bentuk masdar (adverb) yang berasal dari fi'il (verb), yaitu صلح (shaluha). Menurut bahasa aslinya, kata maslahah berasal dari kata shalaha, yashluhu, shalahan (صلح يصلح صلاحا), yang artinya sesuatu yang baik, patut, dan bermanfaat. ${ }^{9}$ Adapun dilihat dari sisi bentuknya, di samping kata mashlahah merupakan bentuk adverb, ia juga merupakan bentuk ism (kata benda) tunggal (mufrad atau singular) dari kata mashalih (jama' atau plural). ${ }^{10}$ Kata mashlahah ini telah diserap ke dalam bahasa Indonesia menjadi maslahat, begitu juga kata manfaat dan faedah.

Secara terminologis, kata maslahat memiliki arti manfa'ah (منفعة), faedah, bagus, baik (kebaikan), guna (kegunaan). ${ }^{11}$ Al-Buthi, dalam bukunya, Dawabit al-Maslahah fi asy-Syari'ah al-Islamiyyah, mengartikan mashlahah sama dengan manfaat yang dapat membuat kesenangan, atau suatu tindakan yang bisa mencegah dengan akibat (hasil) dapat memberikan manfaat kesenangan. Kesenangan ini, kata al-Buthi, dapat dirasakan langsung. Sebab, kesenangan itu merupakan fitrah yang selalu dicari setiap manusia, karena itu, manusia akan selalu berupaya untuk mencari kesenangan ini. ${ }^{12}$

Menurut Abdul Wahhab Khallaf, mashlahah mursalah adalah mashlahah di mana Syari' tidak mensyariatkan hukum untuk mewujudkan mashlahah, juga tidak terdapat dalil yang menunjukkan atas pengakuannya atau pembatalannya. ${ }^{13}$

Sedangkan menurut Muhammad Abu Zahra, definisi mashlahah mursalah adalah segala kemaslahatan yang sejalan dengan tujuan-tujuan

8 Andi Prastowo, Menguasai Teknik-Teknik Koleksi Data Penelitian Kualitatif, (Jogjakarta: Divapress,2010), 13.

9 Muhammad Yunus, Kamus Arab Indonesia (Jakarta: Yayasan Penyelenggaraan Penerjemah dan Penafsir Alquran, 1973), 219.

10 Ibn al-Manzur, Lisan al-'Arab al-Muhit (Beirut: Dar al-Fikr, 1972), Juz II, 348.

${ }^{11}$ Al-Buthi, Dawabit al-Maslahah fi al-Syari'ah al-Islamiyyah (Beirut: Mu'assasah alRisalah, 2001), 27.

${ }^{12}$ Al-Buthi, Dawabit al-Maslahah fi al-Syari'ah al-Islamiyyah (Beirut: Mu'assasah alRisalah, 2001), 28-29.

13 Abdul Wahhab Khallaf, Ilmu Ushul Fiqh (Jakarta: Dar al-Kutub al-Islamiyah, 2010), 75 .

$246 \mid$ JURNAL LISAN AL-HAL 
Syari' (dalam mensyariatkan hukum Islam) dan kepadanya tidak ada dalil khusus yang menunjukkan tentang diakuinya atau tidaknya. ${ }^{14}$

'Izzuddin bin 'Abdussalam (w. $660 \mathrm{H}$ ), ketika menjelaskan makna al-mashalih (jama' atau plural dari kata mashlahah) mengaitkan dengan lawan kata (opposite) dari al-mashalih, yaitu al-mafasid (jama` atau plural dari kata mafsadah). Menurutnya, yang dimaksud dengan al-mashalih itu adalah al-khair (baik), al-naf ' (manfaat), dan al-hasanat (bagus). Sedangkan yang dimaksudkan dengan mafasid itu adalah syurur (buruk), madarah (bahaya), dan sayyi'at (jelek). Dalam Alquran, kata 'Izzuddin lebih lanjut, sering penggunaan kata al-hasanat dimaksudkan dengan almashalih, sedangkan penggunaan kata al-sayyi'at dimaksudkan dengan kata al-mafasid. ${ }^{15}$

Beberapa ulama menyamakan antara mashlahah dan maqashid syari'ah, semisal al-Juwaini yang menggunakan istilah al-maqāsid dan almashālih al-āmmah (kemaslahatan-kemaslahatan umum) secara bergantian. ${ }^{16}$ Al-Ghazali juga mengelaborasi klasifikasi maqashid, yang beliau masukkan ke dalam mashlahah mursalah, yaitu kemaslahatan yang tidak disebut secara langsung dalam nash Islam. ${ }^{17}$ Al-Ghazali mendefinisikan mashlahah sebagai berikut:

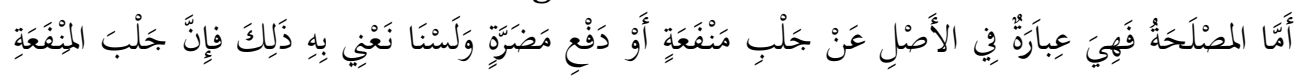

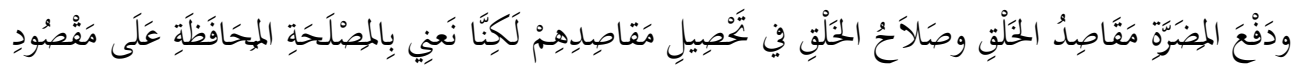

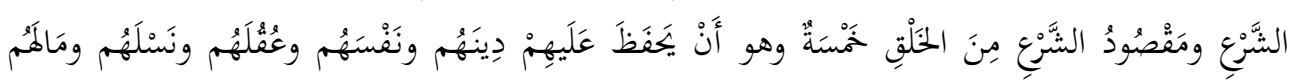

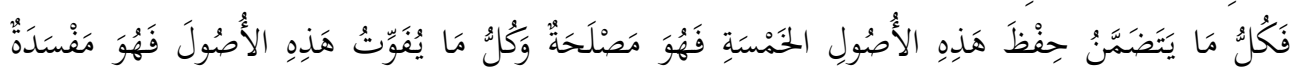

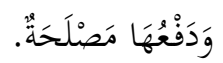

Pada dasarnya mashlahah merupakan ungkapan untuk menarik manfaat dan menolak mudarat. Namun, itu bukanlah yang kami maksud karena menarik manfaat dan menolak mudarat adalah tujuan makhluk dan kelayakan yang dirasakan olehnya dalam mencapai tujuan. Yang kami maksud dengan maslahat adalah menjaga atau memelihara tujuan Syāri', yaitu menjaga agama, jiwa, akal, keturunan, dan harta. Setiap hal yang

\footnotetext{
${ }^{14}$ Muhammad Abu Zahrah, Ushul al-Fiqh, terj. Saefullah Ma'shum, et al., Ushul Fiqih (Jakarta: Pustaka Firdaus, 2005), cet. IX, 424.

15 'Izzuddin bin 'Abdissalam, Qawaid al-Ahkam fi Masalih al-Anam (Kairo: Maktabah al-Kulliyyat al-Azhariyyah, 1994), Juz I, 5.

${ }^{16} \mathrm{Abdu}$ al-Malik al-Juwaini, Maqashid al-Syari'ah al-Islamiyah (t.t.: t.p., t.th.), 253.

17 Jasser Auda, Membumikan Hukum Islam Melalui Maqashid Syari'ah (Bandung: Mizan Media Utama, t.th.), 33.
} 
mengandung dasar-dasar yang lima ini maka itulah maslahat, dan setiap hal yang menghilangkan kelima hal ini maka itulah mafsadat. Adapun menolak mafsadat juga termasuk maslahat. ${ }^{18}$

Mashlahah yang dimaksud al-Ghazali bukanlah kemaslahatan yang dipersepsikan akal manusia. Sebab, mashlahah model ini semata-mata berorientasi pada meraih tujuan-tujuan sesaat manusia, tidak berorientasi pada pencapaian maslahat abadi, yaitu kemaslahatan akhirat di kemudian hari. Al-Ghazali ingin memadukan antara keduanya, walaupun kadang bobot perhatiannya terhadap kemaslahatan ukhrawi lebih menonjol. ${ }^{19}$

Tujuan syariat sering diistilahkan dengan maqashid. Kata maqashid berasal dari bahasa Arab كَقَاصِد yang merupakan bentuk jamak dari kata مَفْصدُ, yang artinya maksud, sasaran, prinsip, atau tujuan. Tujuan syariat itu sendiri adalah jalbu al-mashālih wa dar'u al-mafāsid. ${ }^{20}$

Ibnu 'Asyur menyatakan bahwa maqashid syari'ah adalah maknamakna dan hikmah-hikmah yang menjadi perhatian Syāri' dalam seluruh atau sebagian besar pensyariatan hukum. ${ }^{21}$

Al-Syathibi mendefinisikan mashlahah sebagai berikut:

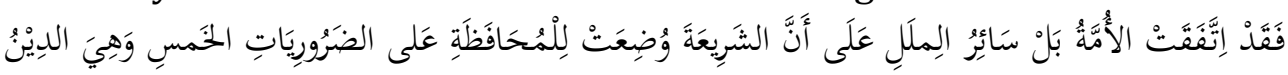

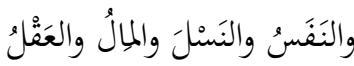

Seluruh umat muslim bahkan seluruh umat dari seluruh agama sepakat bahwa syariat dibuat untuk menjaga/memelihara kebutuhankebutuhan primer manusia yang lima, yaitu agama, jiwa, keturunan, harta, dan akal. 22

Al-Syatibi dalam al-Muwafaqat juga mendefinisikan mashlahah sebagai maslahat yang ditemukan pada kasus baru yang tidak ditunjuk oleh nash tertentu tetapi ia mengandung kemaslahatan yang sejalan (almunasib) dengan tindakan syara'. Kesejalanan dengan tindakan (tasharrufat) syara' dalam hal ini tidak harus didukung dengan dalil tertentu yang berdiri sendiri dan menunjuk pada mashlahah tersebut, tetapi dapat merupakan kumpulan dalil yang memberikan faedah yang pasti (qath'i). Apabila dalil yang pasti ini memiliki makna kulli, maka dalil

18 Abu Hamid al-Ghazali, Al-Mustashfâ min 'Ilmi al-Ushul (Beirut: Dar al-Kotob al'Ilmiyyah), 275.

${ }^{19}$ Nakhe'i, Revitalisasi Ushul Fikih (t.t.: t.p., t.th.), 271.

20 'Izzuddin bin 'Abdissalam, Qawā'idu al-Ahkām fī Mashālihi al-Anām (t.t.: t.p., t.th.), 9.

21 Muhammad Thahir Ibnu Asyur, Maqashid al-Syari'ah al-Islamiyah (Tunisia: Dar al-Salam, 2006), 39.

22 Al-Syatibi, al-Muwafaqāt (Beirut: Dār al-Kutub al-'Ilmiyah, 2005), Juz I, 15.

$248 \mid$ JURNAL LISAN AL-HAL 
kulli yang bersifat pasti tersebut kekuatannya sama dengan satu dalil tertentu. ${ }^{23}$

Sementara itu, al-Thufi membagi pengertian mashlahah menjadi dua, yaitu pengertian secara 'urfi dan pengertian secara syar'i sebagai berikut:

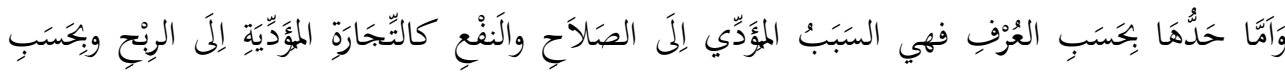

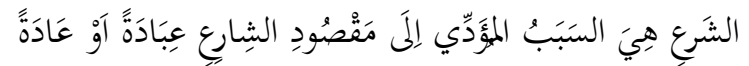

Mashlahah secara 'urfi adalah sebab yang mengantarkan kepada kelayakan dan kemanfaatan, seperti berdagang yang menghasilkan keuntungan, sedangkan mashlahah secara syara' adalah sebab yang mengantarkan kepada tujuan yang dikehendaki Syāri', baik ibadah maupun adat kebiasaan. ${ }^{24}$ Namun, al-Syatibi memberikan batasan mashlahah yang dimaksud, yaitu maslahat yang telah ditetapkan Syāri atau sejalan dengan tujuan-tujuan-Nya, bukan yang berlawanan dengan kehendak Syāri'.25

Mashlahah dan maqashid al-syari'ah dalam pandangan al-Syatibi merupakan dua hal penting dalam pembinaan dan pengembangan hukum Islam. Mashlahah secara sederhana diartikan sebagai sesuatu yang baik dan dapat diterima oleh akal yang sehat. Diterima akal mengandung makna bahwa akal dapat mengetahui dengan jelas kemaslahatan tersebut. Menurut Amir Syarifuddin, ada dua bentuk mashlahah:26

1) Mewujudkan manfaat, kebaikan, dan kesenangan untuk manusia yang disebut jalb al-manafi' (membawa manfaat). Kebaikan dan kesenangan ada yang dirasakan langsung oleh orang yang melakukan sesuatu perbuatan yang diperintahkan, tetapi ada juga kebaikan dan kesenangan yang dirasakan setelah perbuatan itu dilakukan, atau dirasakan di hari kemudian, atau bahkan kelak di akhirat. Segala perintah Allah berlaku untuk mewujudkan kebaikan dan manfaat seperti itu.

2) Menghindari umat manusia dari kerusakan dan keburukan yang disebut dar'u al-mafasid (menghindari kerusakan). Kerusakan dan keburukan pun ada yang langsung dirasakan setelah melakukan perbuatan yang dilarang, ada juga yang merasakan sesuatu kesenangan ketika melakukan perbuatan dilarang itu, tetapi setelah itu yang

${ }^{23} \mathrm{Al}$-Syatibi, al-Muwafaqāt (Beirut: Dār al-Kutub al-'Ilmiyah, 2005), Juz I, 16.

${ }^{24}$ Najamuddin al-Thufi, al-Ta'yin fi Syarh al-Arba'in (t.t.: t.p., t.th.), 239.

${ }^{25}$ Najamuddin al-Thufi, al-Ta'yin fi Syarh al-Arba'in (t.t.: t.p., t.th.), 17.

${ }^{26}$ Amir Syarifuddin, Ushul Fiqh (Jakarta: Kencana Prenada Media Group, 2008), jilid II, cet. IV, 208. 
dirasakannya adalah kerusakan dan keburukan. Misalnya, berzina dengan pelacur yang berpenyakit atau meminum minuman manis bagi yang berpenyakit gula.

Al-Syatibi membagi maqashid kepada dua bagian penting, yakni maksud Syari' (qashd al-syari') ${ }^{27}$ dan maksud mukalaf (qashd al-mukallaf). Menurut al-Syatibi, Allah SWT menurunkan syariat (aturan hukum) semata demi mengambil kemaslahatan dan menghindari kemudaratan (جَلْبُ الْمَصَالِح وَدَرْءُ الََْفَاسِدِ). Dengan bahasa yang lebih mudah, aturan-aturan hukum yang ditetapkan Allah SWT hanya untuk kemaslahatan hamba

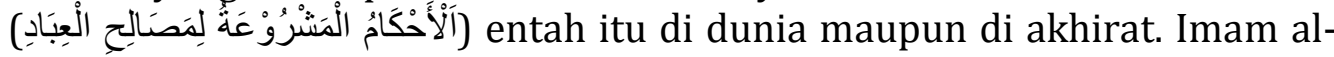
Syatibi mengistilahkan hal ini dengan ungkapan:

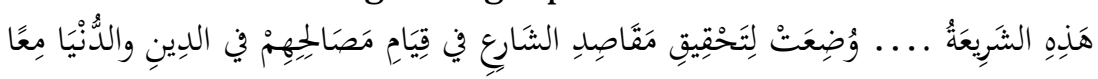

"Sesungguhnya syariat itu bertujuan untuk mewujudkan kemaslahatan manusia di dunia dan di akhirat" 28

Dari pengertian tersebut, dapat dikatakan bahwa tujuan syariat menurut Imam al-Syatibi adalah kemaslahatan umat manusia. Berkaitan dengan hal tersebut, beliau menyatakan bahwa tidak satu pun hukum Allah SWT yang tidak mempunyai tujuan karena hukum yang tidak mempunyai tujuan sama dengan membebankan sesuatu yang tidak dapat dilaksanakan. ${ }^{29}$

Perihal urgensi pengetahuan dan pemahaman terhadap maqashid al-syari'ah merupakan aspek penting dalam melakukan ijtihad karena teori ini menjadi kunci keberhasilan seorang mujtahid dalam ijtihadnya. menurut Wahbah al-Zuhaily, mengetahui maqashid al-syari'ah merupakan yang dharury (keniscayaan) bagi seluruh manusia. Bagi seorang mujtahid dibutuhkan pengetahuan maqashid dalam menggali hukum-hukum dan memahami nash-nash. Sedangkan bagi selain mujtahid, itu dibutuhkan agar dapat mengetahui rahasia dan hikmah-hikmah dari suatu hukum. ${ }^{30}$

27 Menurut al-Syatibi bahwa qashdu al-Syari' dibagi menjadi empat bagian, yaitu (1) Qashdu al-Syari' fi wadl'i al-syari'ah (maksud Allah dalam menetapkan syariat); (2) Qashdu al-Syari' fi qadl'i al-syari'ah li al-ifham (maksud Allah dalam menetapkan syariat agar dapat dipahami); (3) Qashdu al-Syari' fi wadl'i al-syari'ah li al-taklif bi al-muqtadlaha (maksud Allah dalam menetapkan syariat agar dapat dilaksanakan); dan (4) Qashdu alSyari' fi dukhul al-mukallaf tahta ahkam al-syari'ah (maksud Allah mengapa individu harus menjalankan syariat).

28 Al-Syatibi, al-Muwafaqat fi Ushul al-Syari'ah (Beirut: Dar al-Kutub al-'Ilmiyah, 2005), Juz 1, 3.

29 Al-Syatibi, al-Muwafaqat fi Ushul al-Syari'ah (Beirut: Dar al-Kutub al-'Ilmiyah, 2005), Juz 1, 150.

30 Wahbah al-Zuhaily, Al-Fiqhu al-Islamy wa Adillatuhu (t.t.: t.p., t.th.), Juz II, 1017.

$250 \mid$ JURNAL LISAN AL-HAL 
Namun, untuk mengetahui tujuan Syāri' bukan perkara yang mudah. Butuh beberapa disiplin keilmuan yang cukup mumpuni. Dalam hal ini hanya mujtahid yang dapat melakukannya. Sementara orang yang tidak mempunyai kualifikasi menjadi mujtahid, maka tidak ada beban untuk mengetahuinya. ${ }^{31}$

Untuk mengetahui tujuan-tujuan syariat, maka seorang mujtahid harus mampu melewati beberapa tahapan, antara lain:32 pertama, mengetahui dan memahami makna-makna dari nash dan dapat ber-istidlāl dengan nash tersebut berdasarkan penggunaan secara bahasa; kedua, membahas dan menyelesaikan dalil-dalil yang seolah-olah bertentangan menurut mujtahid; ketiga, menganalogi kasus yang belum ada hukumnya terhadap kasus yang telah ada hukumnya setelah diketahui ilat-ilat pensyariatan hukum yang diperoleh dengan metode masālik 'illah; keempat, memproduksi hukum dari sebuah kasus yang terjadi di mana tidak diketahui hukumnya dan mujtahid tidak menemukan dalil. Dasar yang digunakan dalam memutuskan hukum dalam kondisi ini adalah mengacu kepada maksud-maksud syariat secara umum; dan kelima, saat mujtahid tidak menemukan hikmah-hikmah di balik penetapan suatu hukum dan ia merasa lemah dan tidak mampu untuk mengetahui maksud Syāri' maka disebut dengan ta'abbudy.

Untuk bisa memahami urgensi konsep maqashid secara keseluruhan, maka berikut akan diuraikan macam-macam pembagian maqashid atau mashlahah yang diinduksi oleh beberapa ulama kontemporer.

\section{Macam-macam Maqashid al-Syari'ah (Mashlahah)}

Mashlahah sebagai metode hukum yang mempertimbangkan adanya kemanfaatan yang mempunyai akses secara umum dan kepentingan tidak terbatas, serta tidak terikat. Dengan kata lain, mashlahah merupakan kepentingan yang diputuskan secara bebas, namun tetap terikat pada konsep syariat yang mendasar. Karena syariat sendiri ditunjuk untuk memberikan kemanfaatan kepada masyarakat secara umum dan berfungsi untuk memberikan kemanfaatan dan mencegah kemudaratan (kerusakan). Berdasarkan hal tersebut, berikut akan

31 Muhammad Thahir Ibnu 'Asyur, Maqashid al-Syari'ah al-Islamiyyah (t.t.: t.p., t.th.), 18.

32 Muhammad Thahir Ibnu 'Asyur, Maqashid al-Syari'ah al-Islamiyyah (t.t.: t.p., t.th.), 183.

\begin{tabular}{l|l} 
JURNAL LISAN AL-HAL & 251
\end{tabular} 
dipaparkan beberapa pembagian ruang lingkup maqashid syari'ah (mashlahah):

1) Berdasarkan Wilayah Cakupan

Dalam jangkauan hukum yang dicakup oleh maqashid, ulama kontemporer mengklasifikasi maqashid menjadi tiga tingkatan: ${ }^{33}$

a) Maqashid Umum (al-Maqashid al-'Ammah). Maqashid yang dapat diperhatikan pada hukum Islam secara keseluruhan atau mashlahah kulliyah 'àmmah yaitu kemaslahatan yang dampaknya dapat dirasakan oleh seluruh atau mayoritas umat manusia. ${ }^{34}$

b) Maqashid Khusus (al-Maqashid al-Khassah). Yaitu maqashid yang dapat diperhatikan pada salah satu bab tertentu dari hukum Islam. Seperti, kesejahteraan anak pada bab Hukum Keluarga, mencegah kejahatan pada bab Hukum Pidana, dan mencegah monopoli.

c) Maqashid Parsial (al-Maqashid al-Juz'iyyah). Yaitu maslahat yang dampaknya hanya dirasakan oleh sebagian masyarakat atau individuindividu tertentu. ${ }^{35}$ Seperti, maksud (maqashid) terungkapnya kebenaran pada penetapan jumlah saksi tertentu pada kasus- kasus hukum tertentu; maksud (maqashid) menghilangkan kesukaran dalam memperbolehkan orang sakit untuk tidak puasa; dan maksud (maqashid) menjamin makanan para fakir miskin dalam melarang kaum muslimin untuk menyimpan daging pada hari-hari lebaran haji, dan sebagainya.

2) Berdasarkan Kepastian Implementasinya

Maslahat dilihat dari segi kepastian implementasinya menjadi tiga macam: qath'iyyah, zhanniyyah, wahmiyyah. ${ }^{36}$

a) Mashlahah qat'iyyah, yaitu mashlahah yang dalam tataran implementasinya diyakini membawa kebahagiaan di tengah-tengah kehidupan manusia. Mashlahah ini bisa diketahui dengan adanya nash yang tidak mungkin ditakwil, penelitian terhadap beberapa dalil-dalil, dan akal membenarkan adanya manfaat, serta kebalikannya adalah mafsadat. Mashlahah qat'iyyah menurut Ibnu 'Asyur harus memenuhi beberapa syarat, yaitu tsubūt (terbukti adanya), dzuhūr (jelas), indlibāth (reliabel), dan iththirād (berlaku umum). ${ }^{37}$

33 Jasser Auda, Membumikan Hukum Islam melalui Maqashid Syari'ah, 36.

34 Yusuf al-Qardhawi, Madkhal li Dirasah al-Syari'ah al-Islamiyyah (Kairo: Dar alSyuruq, t.th.), 101.

35 Ibid.

${ }^{36} \mathrm{Nu}$ 'man Jughaim, Thuruq al-Kasyfi 'an Maqashid al-Syari', 26.

37 Ibnu Asyur. Maqāsid al-Syarī'ah al-Islāmiyyah, 172. 
b) Mashlahah zhanniyah, adalah mashlahah yang dalam tataran pragmatisnya diduga bakal mendatangkan kedamaian atau kebahagiaan.

c) Mashlahah wahmiyyah, adalah mashlahah yang hidup dalam bayangbayang semu akal manusia, namun dalam kenyataannya dapat menimbulkan kehancuran. Hal ini bisa dikarenakan mafsadat yang tidak tampak jelas, atau mafsadat yang bercampur dengan maslahat.

3) Berdasarkan Hirarkinya

Maslahat dilihat dari segi nilai kekuatan dan pengaruhnya (hirarki) dalam kehidupan masyarakat ada tiga:

a) Dharūriyyat. Maksud dari dharūriyyat adalah tujuan Syāri' berupa kemaslahatan harus terpenuhi yang berakibat tegaknya agama dan kehidupan dunia. Ketika maslahat tersebut terabaikan, niscaya kemaslahatan-kemaslahatan dunia tidak berjalan stabil bahkan bisa berakibat kehancuran dan hilangnya kehidupan. ${ }^{38}$ Dharūriyyat merupakan hal sangat esensial dan menjadi landasan keberlangsungan kehidupan manusia dan mesti ada untuk konsistensi kemaslahatan mereka. Apabila hal itu tidak ada maka akan rusak struktur kehidupan mereka, kemaslahatan mereka tidak konsisten lagi, kekacauan dan kerusakan pun merajalela. ${ }^{39}$ Terdapat lima hal yang termasuk di

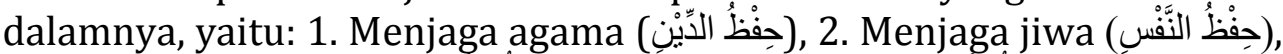

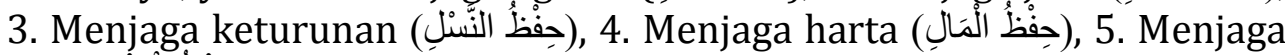

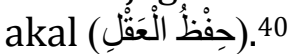

Cara untuk menjaga kelima hal tadi dapat ditempuh dengan dua cara, yaitu: pertama, dari segi adanya (مِنْ جَانِب الْوُجُوْدِ), yaitu dengan cara menjaga dan memelihara hal-hal yang dapat melanggengkan keberadaannya, dan Kedua, dari segi tidak adanya (مِنْ جَانِبِ الْعَدَم), yaitu dengan cara mencegah hal-hal yang menyebabkan ketiadaannya. ${ }^{41}$ Beberapa pakar ushul figh menambahkan perlindungan kehormatan atau hifdhu al-'irdl (حفظظ الْعِرْض). Dharūriyyat dinilai hal-hal esensial bagi kehidupan manusia sendiri. Ada kesepakatan umum bahwa perlindungan dharūriyyat adalah sasaran di balik setiap hukum.

b) Hājiyyat. Merupakan sesuatu yang dibutuhkan agar memperoleh kemaslahatan-kemaslahatan dan teraturnya urusan-urusan manusia

38 Al-Syatibi, al-Muwafaqāt, Juz II, 7.

${ }^{39}$ Abdul Wahhab Khallaf, Ilmu Ushūl al-Fiqh (Beirut: Dar al-Rasyid, t.th.), 185.

40 Al-Syatibi, al-Muwafaqat fi Ushul al-Syari'ah (Beirut: Dar al-Kutub al-'Ilmiyah, 2005), juz II, 7-8.

41 Ibid., 8. 
dari aspek kebagusan. ${ }^{42}$ Apabila hal tersebut tidak ada, maka tidak akan merusak struktur kehidupan mereka dan kekacauan pun tidak merajalela sebagaimana apabila dharūriyyat tidak ada, akan tetapi akan mendapatkan kesulitan dan kesempitan. ${ }^{43}$

c) Tahsiniyyat. Adalah sesuatu yang dibutuhkan agar kondisi dan tasharruf-tasharruf manusia menjadi lengkap, sempurna, dan paripurna. ${ }^{44} \mathrm{Al}$-Syathibi merinci tahsiniyyat menjadi tiga bagian, antara lain: pertama, dalam hal ibadah, seperti melaksanakan ibadah tidak hanya dengan menutup aurat yang wajib saja, tapi dengan menggunakan pakaian yang bagus dan dengan niat taqarrub; kedua, dalam hal adat, seperti adab makan dan minum; ketiga, dalam hal muamalat, seperti larangan menjual benda-benda najis. ${ }^{45}$ Apabila hal ini tidak ada, maka tidak akan merusak struktur kehidupan manusia, sebagaimana apabila dharūriyyat tidak ada, juga tidak pula tertimpa kesulitan sebagaimana apabila hājiyyat tidak ada. Akan tetapi, kehidupan mereka akan janggal dalam pandangan akal dan naluri yang sehat. ${ }^{46}$

Dalam menggabungkan pembagian mashlahah di atas, maka mashlahah dibagi menjadi tiga, yaitu mashlahah mu'tabarah, mashlahah mursalah, dan mashlahah mulgha. Masing-masing mashlahah mu'tabarah dan mashlahah mursalah terbagi ke dalam macam-macam mashlahah tersebut di atas, kecuali mashlahah wahmiyyah karena mashlahah ini termasuk ke dalam kategori mashlahah mulgha. ${ }^{47}$

Kategori mashlahah mu'tabarah dalam seluruh variannya, teoritisi hukum Islam sepakat untuk menjadikannya sebagai pijakan hukum (sumber hukum). Hanya saja diperlukan redefinisi terhadap mashlahah yang mendapatkan legitimasi Syāri'. Mashlahah mursalah dilihat dari segi tidak adanya legitimasi secara tegas dari teks berbeda dengan mashlahah mu'tabarah. Namun, dilihat dari segi bahwa tidak ada satu mashlahah yang benar-benar mashlahah, keluar dari prinsip-prinsip dasar syariat; mashlahah mursalah bisa masuk dalam kategori mashlahah mu'tabarah.

Sementara mashlahah mulgha, sesungguhnya bukan mashlahah. Sebab, pada akhirnya kerusakan yang akan ditimbulkan. Sebagaimana dikemukakan, mashlahah mulgha adalah mashlahah yang bertentangan

\footnotetext{
${ }^{42} \mathrm{Nu}$ 'man Jughaim. Thuruq al-Kasyfi 'an Maqāsid al-Syāri', 28.

43 Abdul Wahhab Khallaf, Ilmu Ushūl al-Fiqh, 186.

${ }^{44}$ Ibnu 'Asyur, Maqāsid al-Syarī’ah al-Islāmiyyah, 2.

${ }^{45}$ Al-Syatibi, al-Muwafaqāt, juz II, 10.

${ }^{46}$ Abdul Wahhab Khallaf, Ilmu Ushūl al-Fiqh, 187.

47 Nakhe'i, Revitalisasi Ushul Fikih, 271.
}

$254 \mid$ JURNAL LISAN AL-HAL 
dengan teks. Di mana teks, sebagai alat komunikasi memiliki dua dimensi, yaitu teks itu sendiri dan tujuan/acuan teks. Setiap bunyi teks pasti mempunyai misi tertentu. Misi tersebut dapat disebut sebagai substansi teks. Mashlahah dapat dikatakan bertentangan dengan bunyi teks bila berseberangan dengan dua dimensinya, yaitu bunyi teks dan substansi teks, atau bertentangan dengan substansi (pesan inti) teks saja. Dengan pemahaman semacam ini, maka mashlahah tidak serta merta dipandang berlawanan hanya karena berbeda dengan bunyi teks atau redaksinya. ${ }^{48}$

Untuk tidak terjebak dalam penggunaan mashlahah secara tidak teratur, maka perlu diperhatikan dua hal berikut: pertama, tentang kemaslahatan macam apa yang dapat mengubah atau dapat menetapkan ketentuan hukum; dan kedua, tentang wilayah hukum yang menjadi objek kemaslahatan.

Oleh sebab itulah, dalam rangka untuk memahami maqashid alsyari'ah (mahslahah) berdasarkan ketentuan dan macam-macam yang telah dipaparkan di atas, menurut Imam al-Syatibi dibutuhkan beberapa syarat, di antaranya:

a) Memiliki pengetahuan bahasa Arab, terutama untuk mendalami kandungan/maksud Alquran.

b) Memiliki pengetahuan tentang al-Sunnah sebagai penjelasan (bayan) bagi Alquran.

c) Mengetahui sebab-sebab turunnya ayat, termasuk dalam masalah ini adalah mengetahui kebiasaan-kebiasaan orang Arab dan situasi yang berlangsung ketika ayat tersebut turun. ${ }^{49}$

Adapun syarat Mashlahah sebagai legislasi hukum Islam menurut Imam al-Syatibi adalah sebagai berikut:

a) Kemaslahatan sesuai dengan prinsip-prinsip yang ada dalam ketentuan Syari' yang secara ushul dan furu'-nya tidak bertentangan dengan nash.

b) Kemaslahatan hanya dapat dikhususkan dan diaplikasikan dalam bidang-bidang sosial (muamalah) di mana bidang ini menerima terhadap rasionalitas dibandingkan dengan bidang ibadah. Karena aturan di dalam muamalah tidak diatur secara rinci dalam nash.

c) Hasil mashlahah merupakan pemeliharaan terhadap aspek-aspek daruriyyah, hajiyah, dan tahsiniyyah. Metode mashlahah adalah sebagai langkah untuk menghilangkan kesulitan dalam berbagai aspek

48 Nakhe'i, Revitalisasi Ushul Fikih, 282-283.

${ }^{49}$ Ibid., 348. 
kehidupan, terutama dalam masalah-masalah sosial kemasyarakatan. ${ }^{50}$ Sesuai dengan firman Allah SWT:

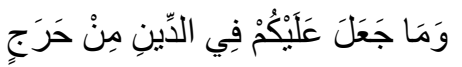

"Dan Dia sekali-kali tidak menjadikan untuk kamu dalam agama suatu kesempitan". (QS. Al-Hajj: 78). ${ }^{51}$

Para faqih atau cendekiawan muslim kontemporer mengembangkan terminologi maqashid tradisional dalam bahasa masa kini meskipun ada penolakan terhadap ide kontemporerisasi terminologi maqashid. Semisal yang diungkapkan Jasser Auda dalam bukunya, Membumikan Hukum Islam melalui Maqashid al-Syari'ah, mengutip pendapat al-Juwaini. Al-Juwaini mengembangkan teori hukum pidana (mazājir) versi al-'Amiri menjadi teori penjagaan ('ismah) yang diekspresikan oleh al-Juwaini dengan istilah hifz al-furūj yang berarti menjaga kemaluan. ${ }^{52}$ Ibnu 'Asyur mengembangkan teori perlindungan keturunan menjadi teori yang berorientasi kepada keluarga dan nilai-nilai moral dalam hukum Islam. ${ }^{53}$

Sama halnya, hifz al-'aqli (perlindungan akal) yang hingga akhirakhir ini masih terbatas pada maksud larangan minum-minuman keras dalam Islam. Sekarang sudah berkembang dengan memasukkan pengembangan pemikiran ilmiah, perjalanan menuntut ilmu, melawan mentalitas taklid, dan mencegah mengalirnya tenaga ahli keluarga. ${ }^{54}$

Sebenarnya hifzu al-irdli sudah menjadi konsep sentral dalam kebudayaan Arab sejak periode pra-Islam. Syair pra-Islam menceritakan bagaimana 'Antarah, seorang penyair terkenal pra-Islam, bertengkar dengan kabilah Damdam terkait dengan pencemaran kehormatannya. Dalam hadis, Nabi SAW menjelaskan bahwa darah, harta, dan kehormatan setiap muslim adalah haram, yang artinya tidak boleh dilanggar. Namun, akhir-akhir ini ungkapan perlindungan kehormatan dalam hukum Islam berangsur-angsur diganti oleh perlindungan harkat dan martabat manusia, bahkan diganti oleh perlindungan hak-hak asasi manusia sebagai maqashid dalam hukum Islam. ${ }^{55}$

50 Al-Syatibi, Al-I'tishom (Beirut: Dar al-Fikr, 1991), 115.

51 Departemen Agama RI, Al-Hidayah: Al-Quran Tafsir Per Kata Tajwid Kode Angka (Jakarta: Kalim, 2011), 342.

52 Jasser Auda, Membumikan Hukum Islam melalui Maqashid Syari'ah (Bandung: Mizan, t.th.), 56.

53 Ibid., 56. t.th.), 20 .

${ }^{54}$ Jasser Auda, Fiqh al-Maqāsid, (Herndon: al-Ma'had al-'Ilmy li al-Fikri al-Islamy,

55 Yusuf al-Qardhawi, Madkhal li Dirasah al-Syariah al-Islamiyyah (Kairo: Dar al256 JURNAL LISAN AL-HAL 
Hifzu al-mal (perlindungan harta) versi al-Ghazali bersama dengan hukuman bagi pencuri versi al-'Amiri dan proteksi uang versi al-Juwaini akhir-akhir ini berkembang menjadi istilah-istilah sosio-ekonomi yang familier, misalnya bantuan sosial, pengembangan ekonomi, distribusi uang, masyarakat sejahtera, dan pengurangan perbedaan antarkelas sosial-ekonomi. Pengembangan ini memungkinkan penggunaan maqashid untuk mendorong pengembangan ekonomi yang sangat dibutuhkan di kebanyakan negara-negara berpenduduk mayoritas muslim. ${ }^{56}$

\section{HASIL \& PEMBAHASAN}

\section{Perkembangan regulasi rumah ibadat dalam konteks negara bangsa (NKRI)}

Keberagamaan adalah salah satu bentuk kebebasan dan hak setiap orang untuk memilih. Hak itu harus diberikan secara utuh oleh siapa pun baik oleh agama itu sendiri ataupun negara. Dalam islam kebebasan memilih agama ini bisa terlihat dengan jelas dalam surat al-kafirun: 6 sebagai berikut:

$$
\text { لَكُمْمْ دِيْكُمْمْ وَلِيَ دِينِ }
$$

"Untukmu agamamu dan untukkulah agamaku"

Tidak hanya memberikan kebebasan memilih agama, tapi juga adanya larangan bagi umat islam untuk memaksa orang lain masuk agama islam. Larangan ini terdapat dalam surat al-baqarah: 256,

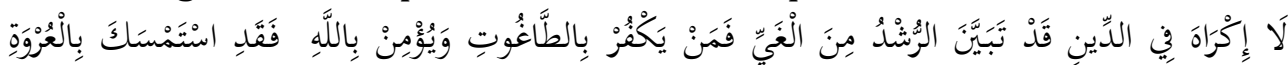

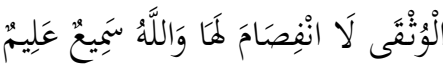

"Tidak ada paksaan untuk (memasuki) agama (islam), sesungguhnya telah jelas jalan yang benar daripada jalan yang sesat. Karena itu barang siapa yang ingkar kepada thaghut dan beriman kepada Allah, maka sesungguhnya ia berpegang kepada tali yang amat kuat yang tidak akan putus. Dan Allah Maha Mendengar lagi Maha Mengetahui"

Kedua ayat di atas menunjukkan bahwa memberikan kebebasan kepada setiap orang untuk memilih agama dan tidak memaksanya untuk masuk ke agama tertentu adalah suatu keharusan dan kebaikan. Bahkan jika ada pemaksaan dari agama tertentu, maka itu akan menyebabkan kehormatan agama tersebut akan tercoreng bahkan akan membahayakan

Syuruq, t.th.), 101.

56 Jasser Auda, Membumikan Hukum Islam melalui Maqashid Syari'ah, 59. 
agama tersebut. Ada kemungkinan orang yang dipaksa itu akan menjadi munafik dan merusak agama dari dalam.

Dalam undang-undang, HAM sangat diperhatikan dan tidak boleh dirampas oleh siapapun termasuk Negara. Salah satu yang menjadi pertimbangan untuk membentuk undang-undang republik Indonesia nomor 39 tahun 1999 adalah bahwa hak asasi manusia merupakan hak dasar yang secara kodrati melekat pada diri manusia, bersifat universal dan langgeng. ${ }^{57}$

Salah satu bentuk hak asasi bebas memilih agama adalah hak melaksanakan ibadah dan membangun rumah ibadat.58 Itu merupakan sesuatu yang niscaya, karena tidak mungkin dikatakan bebas memilih agama kalau dia dilarang melaksanakan ajaran agamanya dan juga tidak mungkin dikatakan bebas pula kalau untuk mendirikan rumah ibadat harus ada pertumpahan darah. Paul M. Taylor juga mengatakan bahwa hak untuk beribadah mencakup dua hal, hak untuk mendirikan rumah ibadat dan hak untuk menjalankan atau menjaga rumah ibadat tersebut. ${ }^{59}$

Akan tetapi apabila dilihat ketentuan internasional pada Pasal 18 ayat (3) ICCPR, ada ruang bagi pembatasan hak beragama apabila dipenuhi 5 (lima) elemen perlindungan, yaitu: pembatasan demi keamanan publik (restriction for protection of public safety); pembatasan untuk melindungi ketertiban masyarakat (restriction for the protection of publik order); pembatasan untuk melindungi kesehatan masyarakat (restriction for the protection of pubic health); pembatasan untuk melindungi moral masyarakat (restriction for the protection morals); dan pembatasan untuk melindungi kebebasan mendasar dan kebebasan orang lain (restriction for the protection of the (fundamental) rights and freedom of others). ${ }^{60}$

Apabila dikaji lebih lanjut hubungan antara agama dan negara, Indonesia termasuk atau menggunakan paradigma substantif. Pada kategori ini, hubungan antara negara dengan agama bersifat simbiotik, hubungan yang salig memerlukan. Menurut paradigma ini, negara memerlukan panduan etika dan moral sebagaimana diajarkan oleh agama,

${ }^{57}$ Undang-Undang Republik Indonesia Nomor 39 Tahun 1999 tentang Hak Asasi Manusia, 1.

58 Undang-undang Dasar Tahun 1945 Pasal 28E Ayat: (1), Pasal 28I ayat: (1), Pasal 29 Ayat: (2), dan Pasal 22 Undang-undang (UU) Nomor 30 tahun 1999 tentang HAM.

59 Paul Taylor, The Right to Manifest Religious Belief and Applicable Limitations (Cambridge: Cambridge University Press, 2005), 242.

60 Rini Fidiyani, Jurnal (Dinamika Pembangunan Rumah Ibadah bagi Warga Minoritas di Jawa Tengah), Fakultas Hukum Universitas Negeri Semarang (UNNES), 5-6.

$258 \mid$ JURNAL LISAN AL-HAL 
sedangkan agama memerlukan kawalan negara untuk kelestarian dan eksistensinya. Dalam konteks ini, Pancasila merupakan contoh yang tepat untuk paradigma ini. Ini berbeda dengan paradigm sekuler yang menginginkan pemisahan secara tegas antara agama dan negara atau paradigma dari kelompok yang secara formalistik bersesuaian dengan faham fundamentalis seperti doktrin innal al-Islam al Din wa al-Daulah (sesungguhnya Islam itu agama dan negara) (Thohir, 2010: 167-168).61

Rumah ibadat merupakan salah satu symbol agama yang paling penting karena setiap agama memiliki ciri khusus untuk rumah ibadat mereka masing-masing. Karena rumah ibadat itu sebagai symbol,62 masing-masing agama berlomba-lomba untuk membangun dan memegahkan rumah ibadat mereka. Kadang orang yang sangat fanatik, tidak memberikan kaum minoritas membangun rumah ibadat dengan dalih mereka adalah mayoritas. Tidak jarang fanatisme seperti ini berujung pada ketidak harmonisan bahkan sampai pada pembantaian umat minoritas tersebut.

Dengan demikian, rumah ibadah perlu memiliki perhatian khusus dari para tokoh agama dan pemerintah, dengan cara berunding dan berembuk bareng untuk membuat peraturan. Ini dimaksudkan untuk menghindari terjadinya konflik antar umat beragama yang menyebabkan keharmonisan tidak dapat terjalin. Inilah salah satu yang melatar belakangi munculnya keputusan bersama menteri agama dan menteri dalam negeri no. 01/ber/mdn-mag/1969, tentang pelaksanaan tugas aparatur pemerintahan dalam menjamin ketertiban dan kelancaran pelaksanaan pengembangan dan ibadat agama oleh pemelukpemeluknya. ${ }^{63}$

Pada tahun 1967 terjadi penolakan pembangunan gereja di Meolaboh, aceh. Umat muslim berargumen bahwa di daerah tersebut dihuni oleh mayoritas umat muslim sehingga mereka tidak mentoleransi adanya pembangunan gereja. Disisi lain umat kristen mengatakan bahwa mendirikan rumah ibadat adalah salah satu bentuk kebebasan beragama yang harus dilindungi oleh negara. Tidak hanya kasus penolakan saja, bahkan sampai pada pembakaran, perusakan dan lain sebagainya. Dengan

61 Thohir, Mudjahirin, (2010). Fundamentalisme Keagamaan dalam Perspektif Kebudayaan. Jurnal Analisa, XVII (02). 165-174.

62 'Alauddin Abu Bakar bin Mas'ud bin Ahmad al-kasani al-hanafi, Bada'I'u alshana'I' fi tartib al-syara'i', dar al-kutub al-ilmiyah, 1986, (maktabah syamela), Juz:1, 282.

63 Rumadi, "Mengawal Pluralisme di Tengah Kegamangan Negara" dalam Ahmad Suaedy, dkk. Politisasi Agama dan Konflik Komunal: Beberapa Isu Penting di Indonesia (Jakarta: The Wahid Institute, 2007), 10-11. 
demikian, pemerintah memandang perlu untuk membuat regulasi yang berkaitan dengan rumah ibadah. ${ }^{64}$

Sebagaimana disinggung oleh Much. Nur Ichwan, diterbitkannya SKB Dua Menteri ini selain bertujuan untuk meredam konflik di seputar pendirian rumah ibadah, tujuan lainnya adalah untuk merespons isu maraknya Kristenisasi di Indonesia. Sebagian kalangan Islam merasa khawatir akan upaya-upaya Kristenisasi yang gencar dilakukan umat Kristen. Banyaknya konflik di seputar pendirian rumah ibadah dan ketakutan sebagian umat Islam akan upaya-upaya Kristenisasi tersebut kemudian ditanggapi secara serius oleh pemerintah Orde Baru dengan menerbitkan SKB Dua Menteri No.1/BER/mdn-mag/1969. Penerbitan SKB Dua Menteri ini dapat dimengerti karena rezim Orde Baru sangat menekankan stabilitas politik. Menurut penulis, penerbitan SKB Dua Menteri ini lebih dimaksudkan untuk mendapatkan simpati umat beragama, khususnya umat Muslim yang notabene merupakan kelompok mayoritas di negeri ini. Simpati atau dukungan dari umat beragama (Islam) sangat penting artinya bagi Orde Baru untuk mendukung proyek pembangunan nasional. 65

Yang dimaksud dengan rumah ibadah dalam peraturan bersama menteri agama dan menteri dalam negeri nomor: 9 dan nomor: 8 tahun 2006 adalah Rumah ibadah merupakan bangunan yang memiliki ciri-ciri tertentu yang khusus dipergunakan untuk beribadat bagi para pemeluk masing-masing agama secara permanen, tidak termasuk tempat ibadat keluarga. ${ }^{66}$

Sementara didalam KBBI, rumah ibadah di artikan sebagai bangunan tempat beribadat (masjid, gereja, kuil, dsb); ${ }^{67}$, dari definisi ini, setiap bangunan yang dijadikan sebagai tempat ibadah baik itu milik pribadi seseorang atau milik bersama masuk dalam kategori rumah ibadah. Definisi rumah ibadah yang lain adalah sebuah tempat yang digunakan oleh umat beragama untuk beribadah menurut ajaran agama Januari 2009.

64 Suhadi Cholil, "Rumitnya Perizinan Rumah Ibadah", Suara Pembaruan, 31

${ }^{65}$ Ichwan, Moch. Nur, "Menuju Governansi Humanis Agama: Refleksi Ulang Tahun Ke- 64 Kementerian Agama". Makalah disampaikan dalam seminar HUT Kementerian Agama RI, Jakarta 21 Januari 2011.

${ }^{66}$ peraturan bersama menteri agama dan menteri dalam negeri nomor : 9 tahun 2006 nomor : 8 tahun 2006 (tentang pedoman pelaksanaan tugas kepala daerah/wakil kepala daerah dalam pemeliharaan kerukunan umat beragama, pemberdayaan forum kerukunan umat beragama, dan pendirian rumah ibadat).

${ }^{67} \mathrm{KBBI}$ ofline.

$260 \mid$ JURNAL LISAN AL-HAL 
atau kepercayaan mereka masing-masing.68 Definisi ini tidak jauh beda dengan definisi yang ditawarkan oleh KBBI, hanya saja dikaitkan dengan agama dari masing-masing rumah ibadah tersebut.

Dalam keputusan bersama menteri agama dan menteri dalam negeri no. 01/ber/mdn-mag/1969, rumah ibadat memiliki ruang yang sempit dan hanya diatur dalam dua pasal yakni pasal 4 dan pasal 5 . Keputusan bersama menteri agama dan menteri dalam negeri tersebut secara rinci berisi tentang pendirian rumah ibadat dan solusi-solusi dari permasalahan rumah ibadat. Pasal empat berisi tiga ayat yakni berkenaan dengan keharusan rumah ibadat untuk mendapatkan izin dari pemerintah daerah, pertimbangan-pertimbangan yang harus diperhatikan oleh pemerintah daerah dalam memberikan izin. Berikut adalah bunyi dari keputusan tersebut: 1) Setiap pendirian rumah ibadat perlu mendapatkan ijin dari Kepala Daerah atau pejabat pemerintahan dibawahnya yang dikuasakan untuk itu, 2) Kepala Daerah atau pejabat yang dimaksud dalam ayat (1) pasal ini memberikan ijin yang dimaksud, setelah mempertimbangkan: pendapat Kepala Perwakilan Departemen Agama setempat, Planologi dan kondisi dan keadaan setempat, dan 3) Apabila dianggap perlu, Kepala Daerah atau pejabat yang ditunjuknya itu dapat meminta pendapat dari organisasi-organsasi keagamaan dan ulama / rokhaniawan setempat. 69

Selanjutnya, pasal yang kelima juga mengandung tiga ayat dan masing-masing ayat tidak khusus berkaitan dengan rumah ibadat, akan tetapi lebih berkaitan dengan masalah keagamaan. Pasal kelima ini, membicarakan tentang tindakan pemerintah daerah dalam melerai konflik yang terjadi antar umat beragama, baik berhubungan dengan rumah ibadah atau tidak. Jika perselisihan itu sampai pada perbuatan yang melanggar hukum dan ada aturan khusus yang mengaturnya, maka pemerintah daerah harus menyerahkan kasus itu pada pihak yang berwajib.

(1) Jika timbul perselisihan atau pertentangan antara pemelukpemeluk agama yang disebabkan karena kegiatan penyebaran/penerangan /penyuluhan /ceramah/khotbah agama atau pendirian rumah ibadat, maka Kepala Daerah segera mengadakan 2019.

68 https://id.wikipedia.org/wiki/Tempat ibadah, diakses pada rabu 04 desember

${ }^{69}$ Keputusan bersama menteri agama dan menteri dalam negeri no. 01/ber/mdnmag/1969, tentang pelaksanaan tugas aparatur pemerintahan dalam menjamin ketertiban dan kelancaran pelaksanaan pengembangan dan ibadat agama oleh pemelukpemeluknya. 
penyelesaian yang adil dan tidak memihak. (2) Dalam hal perselisihan/pertentangan tersebut menimbulkan tindakan pidana, maka penyelesaiannya harus diserahkan kepada alat-alat penegak hukum yang berwenang dan diselesaikan berdasarkan hukum. (3) Masalah-masalah keagamaan lainnya yang timbul dan diselesaikan oleh Kepala Perwakilan Departemen Agama segera dilaporkannya kepada Kepala Daerah setempat. ${ }^{70}$

Ahmad asroni juga megatakan bahwa keputusan bersama atau peraturan bersama menteri agama dan menteri dalam negeri ini tidak spesifik membahas tentang rumah ibadat, akan tetapi secara umum membahas tentang pengembangan dan penyiaran agama. ${ }^{71}$

Ihsan Ali Fauzi dkk menambahkan keterangan tentang pasal ini bahwa kepala daerah hanya mau mengeluarkan surat izin pendirian rumah ibadat jika telah memperoleh rekomendasi dari Laksusda (Pelaksana Khusus Daerah). Laksuda merupakan lembaga keamanan pada masa orde baru dibawah komando pemilihan keamanan dan ketertiban (KOPKAMTIB). Laksuda adalah organ KOPKAMTIB ditingkat lokal dan kebanyakan terdiri dari militer. Standar yang digunakan untuk mengeluarkan izin adalah stabilitas sosial dan aspek keamanan. Jika izin itu telah dikeluarkan oleh Laksuda barulah gubernur atau bidang kesejahteraan rakyat akan mengeluarkan izin. ${ }^{72}$

Pada pasal berikutnya dalam SKB Dua Menteri ini disebutkan jika terjadi perselisihan, termasuk perselisihan terkait rumah ibadah, maka kewenangan penyelesainnya ada di tangan kepala daerah. Jika tidak selesai dan menimbulkan tindak pidana, maka penegak hokum akan menangani sesuai hukum yang berlaku. ${ }^{73}$

Selanjutnya, peraturan yang mengatur tentang rumah ibadah adalah peraturan bersama menteri agama dan menteri dalam negeri nomor 8 dan 9 tahun 2006. Peraturan ini dibuat dalam rangka melengkapi peraturan atau keputusan bersama menteri agama dan menteri dalam

\footnotetext{
70 keputusan bersama menteri agama dan menteri dalam negeri no. 01/ber/mdnmag/1969, tentang pelaksanaan tugas aparatur pemerintahan dalam menjamin ketertiban dan kelancaran pelaksanaan pengembangan dan ibadat agama oleh pemelukpemeluknya.

${ }^{71}$ Ahmad Asroni, (jurnal: Menyegel Rumah Tuhan), 65.

72 Ihsan Ali Fauzi, dkk, Kontrofersi Gereja di Jakarta, (Yogyakarta: CRCS UGM, 2011), 34 .

73 keputusan bersama menteri agama dan menteri dalam negeri no. 01/ber/mdnmag/1969, tentang pelaksanaan tugas aparatur pemerintahan dalam menjamin ketertiban dan kelancaran pelaksanaan pengembangan dan ibadat agama oleh pemelukpemeluknya.
}

$262 \mid$ JURNAL LISAN AL-HAL 
negeri no. 01/ber/mdn-mag/1969. PBM No. 8/2006 dan 9/2006 adalah jawaban dari tuntutan masyarakat yang menghendaki adanya revisi atas keputusan bersama menteri agama dan menteri dalam negeri no. 01/ber/mdn-mag/1969.

Merespons berbagai dinamika yang berkembang di masyarakat terkait SKB Dua Menteri No.01/BER/mdn-mag/1969, Menteri Agama bersama Menteri Dalam Negeri, Menteri Hukum dan HAM, Jaksa Agung, dan pejabat lain yang terkait mengadakan rapat untuk membahas revisi SKB Dua Menteri tersebut dan melahirkan draf awal rancangan peraturan baru tentang kerukunan umat beragama dan pendirian rumah ibadah. Draf revisi SKB Dua Menteri menuai kontroversi di kalangan umat beragama. Kalangan yang setuju atas draf revisi SKB Dua Menteri yaitu Majelis Ulama Indonesia (MUI), Partai Keadilan Sejahtera (PKS), dan Front Pembela Islam (FPI) menilai bahwa peraturan ini lebih baik karena secara detail mengatur kerukunan umat beragama, terutama pengaturan pendirian rumah ibadah. Sementara pihak yang menentang draf revisi SKB Dua Menteri yaitu Partai Damai Sejahtera, Aliansi Masyarakat Peduli Kebebasan Beribadah, Nusa Tenggara Timur, dan beberapa komunitas Muslim di Bali dan Nusa Tenggara Barat menilai bahwa peraturan baru hanya memperburuk keadaan. Kendatipun demikian, PBM No. 9/2006 dan No. 8/2006 dengan segala keterbatasannya dipandang sebagai jalan tengah oleh lembaga-lembaga agama 'resmi' di Indonesia seperti Konferensi Waligereja Indonesia (KWI), Persekutuan Gereja Indinesi (PGI), Majelis Ulama Indonesia (MUI), Parisada Hindu Dharma Indonesia (PHDI), dan Wali Umat Buddha Indonesia (Walubi). Pada 21 Maret 2006, Menteri Agama Maftuh Basyuni bersama Menteri Dalam Negeri Muhammad Ma'ruf menandatangani PBM No. 9/2006 dan No. 8/2006. ${ }^{74}$

Hasil yang ingin dicapai oleh terbentuknya PBM No. 9/2006 dan No. 8/2006 adalah terwujudnya kerukunan umat beragama yang menjadi

74 Ihsan Ali-Fauzi, dkk. Kontroversi Gereja, 35. Pembahasan rancangan PBM No. 9/2006 dan No. 8/2006 berjalan alot. Menurut KH Ma'ruf Amin Ketua Majelis Ulama Indonesia Bidang Fatwa, salah satu poin yang menuai perdebatan adalah ketentuan tentang pengguna rumah ibadah. Pihak MUI pada awalnya menginginkan pengguna rumah ibadah minimal 100 orang, Namun karena keberatan dari kelompok non-Mus- lim persyaratatan pengguna rumah ibadah disepakati menjadi mininal 90 orang. Poin lain yang menjadi perdebatan adalah izin sementara bagi pemanfaatan gedung sebagai rumah ibadah. Pada proses pembahasan rancangan PBM, MUI menolak adanya izin sementara tersebut. Menurut MUI, rumah ibadah yang tidak berizin seharusnya mengurus persyaratan mulai awal. Namun karena keberatan dari kelompok non-Mus- lim disepakatilah ijin sementara bagi pemanfaatan gedung sebagai rumah ibadah. Indopos, 23 Maret 2006, "Revisi SKB Dua Menteri Disahkan”.

$$
\text { JURNAL LISAN AL-HAL } \mid 263
$$


pilar dari kerukunan nasional. ${ }^{75}$ Kerukunan umat beragama akan berpengaruh besar terhadap stabilitas suatu negara, sehingga banyak negara-negara luar yang akibat ketidak rukunan umat beragamanya, menjadi rusak dan hancur. PBM No. 9/2006 dan No. 8/2006 telah membawa dampak terhadap pemeliharaan kerukanaa umat beragama di indonesia ini. Salah satu yang membuktikan dan menginformasikan hal ini adalah Puslitbang Kehidupan Keagamaan Tahun 2007. Dalam hasil penelitiannya pada tahun 2007 itu, ia mengungkapkan bahwa sosialisasi PBM tentang rumah ibadat berpengaruh terhadap pemeliharaan kerukunan umat beragama sebesar $17,4 \%$.

Pemerintah sebenarnya sudah mengantisipasi terjadinya konflik antar umat beragama khususnya perusakan tempat ibadah dengan mengeluarkan regulasi sejak lama, yaitu dengan keluarnya SKB pada 1969. Akan tetapi Surat Keputusan Bersama (SKB) No. 1/Ber/MDN-MAG/1969 ini dianggap terlalu diskriminatif dan tidak rincinya pegaturan mengenai pendirian rumah ibadat. Oleh karena itu Pemerintah mengeluarkan PMB No. 9 dan 8 Tahun 2006. Ali Fauzi dkk mencatat sejak 1969-2006 terjadi lebih dari 1000 kasus konflik pendirian rumah ibadat terutama berkaitan dengan pendirian gereja. ${ }^{76}$ PMB 9 dan 8 Tahun 2006 mengatur tiga hal, yaitu: pembinaan kerukunan umat beragama melalui pembentukan Forum Kerukunan Umat Beragama, prosedur pendirian rumah ibadat, dan penyelesaian bila terjadi konflik. ${ }^{77}$

Isi PBM No. 8/2006 dan 9/2006 secara rinci dan berkenaan dengan rumah ibadat adalah sebagai berikut: Pasal pertama yang menyinggung rumah ibadat adalah pasal nomor 6 . Pasal ini hanya menyinggung sedikit tentang rumah ibadat, yakni tentang kewajiban dan tugas bupati atau walikota. Dalam pasal ini, bupati diwajibkan mengeluarkan izin mendirikan bangunan rumah ibadat jika telah memenuhi syarat dan ketentuan yang berlaku.

Kemudian pada bab IV dan V, rumah ibadat diterangkan secara rinci dalam tujuh pasal, namun tetap terbatas pada pendirian dan perizinan rumah ibadat. Pada bab IV pasal ke 13 menjelaskan tentang

75 M.Yusuf Asry, pendirian rumah ibadah di indonesia (pelaksanaan peraturan bersama menteri agama dan menteri dalam negeri no. 9 dan 8 tahun 2006), kementerian agama ri badan litbang dan diklat puslitbang kehidupan keagamaan jakarta, 2011.

76 Ali-Fauzi, Ihsan, dan kawan-kawan. (2011). Kontroversi Gereja di Jakarta. (Yogyakarta: CRCS Universitas Gajah Mada, 2011), 13.

77 Noorbani, M. Agus.. Pendiria Rumah Ibadat di Kota Cirebon Pasca Pemberlakuan Peraturan Bersama Menteri Agama dan Menteri Dalam Negeri Nomor 9 dan 8 Tahun 2006. Harmoni - Jurnal Multikultural dan Multireligius, 14(3), (2015), 10.

$264 \mid$ JURNAL LISAN AL-HAL 
dasar pendirian rumah ibadat harus berdasarkan pada keperluan nyata dan komposisi jumlah penduduk. Pendirian rumah ibadat tidak boleh dilaksanakan jika kerukunan, ketentraman dan ketertiban umum terusik dan terganggu. ${ }^{78}$

Pemeliharaan kerukunan beragama merupakan tanggung jawab bersama antara pemerintah dan umat beragama. Pemerintah diwakili gubernur atau bupati/walikota untuk tingkat kabupaten/kota. Sementara aspirasi umat beragama diwakili oleh pemimpin agama 'resmi' yang tergabung dalam FKUB. Anggota FKUB berjumlah 21 orang untuk tingkat provinsi dan 17 orang untuk tingkat kabupaten atau kota. ${ }^{79}$ Kuota perwakilan masing-masing agama berdasarkan perbandingan jumlah pemeluk agama masing-masing daerah, minimal satu agama diwakili oleh satu orang. PBM No. 9/2006 dan No. 8/ 2006 tepatnya pasal 14 mengatur bahwa pendirian rumah ibadah wajib memenuhi beberapa syarat, yaitu (1) Daftar nama dan Kartu Tanda Penduduk (KTP) 90 orang pengusul rumah ibadah yang disahkan oleh pejabat sesuai dengan batas wilayahsetempat, (2) KTP 60 orang warga setempat yang disahkan oleh kepala desa atau lurah, (3) Rekomendasi tertulis dari kantor Departemen Agama kabupaten atau kota setempat, (4) Rekomendasi dari FKUB kabupaten setempat. Rekomendasi tersebut harus didasarkan pada musyawarah mufakat dan tidak dapat dilakukan dengan voting. ${ }^{80}$

Selanjutnya pada bab $\mathrm{V}$, menerangkan tentang izin sementara pemanfaatan bangunan gedung dan diatur dalam tiga pasal yakni pasal 18, 19 dan 20. pemanfaatan bangunan gedung sementara harus mendapat izin dari bupati atau walikota berupa surat keterangan pemberian izin sementara. Untuk mendapatkan surat keterangan itu, hendaknya para pemohon memenuhi dua syarat, yakni baik fungsi (harus mengacu pada peraturan perundang-undangan tentang bangunan gedung) dan pemeliharaan kerukunan umat beragama serta ketentraman dan ketertiban masyarakat. Instrumen yang dapat dilihat untuk memenuhi ketentraman dan ketertiban masyarakat adalah pertama: izin tertulis pemilik bangunan, kedua: rekomendasi tertulis lurah atau kepala desa, ketiga: pelaporan tertulis kepada FKUB kabupaten atau kota, keempat: pelaporan tertulis kepada kepala kantor departemen agama kabupaten

78 Ibid.

${ }^{79}$ Ihsan Ali-Fauzi, dkk., Kontroversi Gereja, 36.

80 peraturan bersama menteri agama dan menteri dalam negeri nomor: 9 dan nomor: 8 tahun 2006 (tentang pedoman pelaksanaan tugas kepala daerah/wakil kepala daerah dalam pemeliharaan kerukunan umat beragama, pemberdayaan forum kerukunan umat beragama, dan pendirian rumah ibadat). 
atau kota. Jangka waktu izin sementara pemanfaatan bangunan gedung ini adalah maksimal dua tahun. ${ }^{81}$

Jika terjadi konflik di seputar pendirian rumah ibadah, maka pertama-tama diselesaikan melalui musyawarah mufakat bersama masyarakat setempat. Jika tidak tercapai, maka pemerintah kabupaten atau kota wajib memfasilitasi musyawarah secara adil dan netral. Manakala mediasi pemerintah kabupaten atau kota menemui jalan buntu, penyelesaian akhir ditetapkan melalui pengadilan setempat. ${ }^{8283}$

Human Rights Watch dalam kajiannya menjumpai bahwa PBM ini efektif digunakan oleh kelompok militan untuk menghalangi pembangunan rumah ibadah. ${ }^{84}$ Kelompok ini berargumen bahwa tindakan mereka menghalangi pembangunan atau menutup rumah ibadah dibenarkan karena pengantur minoritas yang membangun rumah kurang memenuhi persyaratan, menuduh mereka menggunakan data diri atau tanda tangan palsu, atau alasan bahwa pembangunan rumah ibadat akan menganggu ketentraman dan kerukunan umat beragama di wilayah tersebut. Meski demikian, PBM tidak selalu menjadi alasan di balik konflik. Hasil kajian Asry, ${ }^{85}$ Dachlan, ${ }^{86}$ Ahmad Nur,87 di Tapanuli Utara menemukan fakta lain bahwa meski beragai persyaratan yang ada dalam PBM telah dipenuhi Panitia Pembangunan Masjid AlMunawwar, Sarulla, akan tetapi masyarakat setempat tidak berkenan masjid tersebut didirikan dengan alas an karena "tidak patut dan tidak layak". Alasan ini seperti mengada-ada dan memiliki nuansa ketidaksukaan dari kelompok agama mayoritas setempat. ${ }^{88}$

81 Ibid.

${ }^{82}$ Ihsan Ali-Fauzi, dkk., Kontroversi Gereja, 37.

83 peraturan bersama menteri agama dan menteri dalam negeri nomor: 9 dan nomor: 8 tahun 2006 (tentang pedoman pelaksanaan tugas kepala daerah/wakil kepala daerah dalam pemeliharaan kerukunan umat beragama, pemberdayaan forum kerukunan umat beragama, dan pendirian rumah ibadat).

84 Human Rights Watch. Atas Nama Agama: Pelanggaran terhadap Minoritas Agama di Indonesia; (2013). 50.

85 Asry, Yusuf. Miskomunikasi dan Robohnya Sendi Harmoni Antar Kristen-Islam dalam Pembangunan Masjid Al-Munawar Narhornop Marsada, Kabupaten Tapanuli Utara. Jurnal Harmoni, (2014). 52-64.

86 Dachlan, Muh. Dinamika Pendirian Gereja Kristen Songka dan Gereja Toraja Jemaat Marannu di Kota Palopo. Jurnal SmaRT, (2015). 69-81;

87 Ahmad Nur. Pesan Dakwah dalam Penyelesaian Konflik Pembangunan Rumah Ibadah (Kasus Pembangunan Rumah Ibadah antara Islam dan Kristen Desa Payaman). Jurnal Fikrah, (2013). 335-364;

88 Noorbani, M. Agus. Pendiria Rumah Ibadat di Kota Cirebon Pasca Pemberlakuan Peraturan Bersama Menteri Agama dan Menteri Dalam Negeri Nomor 9 dan 8 Tahun 2006.

266 JURNAL LISAN AL-HAL 
Dari hasil kajian para pemikir tersebut, sangat jelas bahwa ada dampak positif (kelebihan) dan negatif (kekurangan) yang ditimbulkan dari PBM No. 9/2006 dan No. 8/2006. Ada pula yang mengatakan bahwa PBM No. 9/2006 dan No. 8/2006 ini memiliki celah diskriminasi, yaitu:

Pertama, politisasi kewenangan pemerintah daerah dalam mengeluarkan IMB. Fakta ini misalnya dapat ditilik dari salah seorang calon kepala daerah di Bogor yang dalam kampanyenya menjanjikan untuk tidak mengeluarkan IMB bagi agama tertentu. Politisasi bentuk lainnya adalah manakala eksekutif daerah berasal dari partai bercorak Islamis yang memanfaatkannya untuk menerapkan agenda Islamis di daerahnya. Di antaranya adalah menghentikan laju pertumbuhan rumah ibadah nonIslam. Kewenangan rekomendasi di tangan pemerintah daerah tanpa adanya kontrol ketat dari legislatif dan masyarakat sipil amat rentan terhadap lahirnya kebijakan yang diskriminatif.

Kedua, keanggotaan FKUB yang didasarkan pada representasi pemeluk agama. Artinya, semakin banyak suatu agama memiliki pemeluk di suatu daerah, maka semakin besar pula jumlah keanggotaannya di FKUB. Di level pengambilan keputusan, kendatipun dalam PBM No. 9/2006 dan No. 8/ 2006 disebutkan bahwa keputusan FKUB didasarkan atas musyawarah mufakat, namun dalam realitasnya keputusan FKUB seringkali diambil melalui voting. Hal ini tentu saja merugikan agama minoritas yang hanya bisa menempatkan sedikit wakilnya di FKUB. Ketentuan representasi juga menimbulkan masalah bagi agama-agama yang memiliki banyak denominasi.

Ketiga, persyaratan dukungan masyarakat yang berwujud 60 KTP berpotensi menimbulkan diskriminasi. Di suatu wilayah yang masyarakatnya toleran, persyaratan tersebut tentu saja tidak menjadi masalah, namun di daerah yang memiliki sikap toleransi yang rendah pastinya akan menghambat pendirian rumah ibadah. Selain itu, persyaratan dukungan masyarakat juga rawan dijadikan lahan bisnis. Dalam beberapa kasus, persyaratan dukungan masyarakat ini menjadi celah kelompok tertentu untuk mendapatkan uang. Artinya, kelompok tertentu menjanjikan dukungan dari masyarakat jika panitia pembangunan rumah ibadah membayar sejumlah uang. Jika tidak dipenuhi, maka pembangunan akan dihambat dan bahkan dukungan yang telah terkumpul akan dipermasalahkan. Bagi panitia pembangunan rumah ibadah yang memiliki dana lebih, situasi ini tidak menjadi masalah. Namun

Harmoni - Jurnal Multikultural dan Multireligius, (2015). 11-12.

\begin{tabular}{l|l} 
JURNAL LISAN AL-HAL & 267
\end{tabular} 
bagi merekayang tidak memiliki sumber daya finansial yang besar, persyaratan dukunganmasyarakat tersebut acapkali menjadi masalah. ${ }^{89}$

Menurut Ahmad Asroni kelemahan PBM No. 9/2006 dan No. 8/2006 ini adalah kurang lebih merupakan wujud keberpihakan negara terhadap pemeluk agama mayoritas. ${ }^{90} \mathrm{Hal}$ ini dapat dilihat dari proses perumusan regulasi tersebut. Sebagaimana diketahui bahwa wajah politik keagamaan di Indonesia pasca tumbangnya Orde Baru (masa Reformasi) lebih mengarah kepada politik representasi dan konfesionalisasi. Politik representasi dan konfesionalisasi merupakan pilihan pragmatis untuk berpihak kepada mayoritas, dengan logika legitimasi pemaknaan bahwa demokrasi merupakan "pemerintahan yang berada di tangan mayoritas". ${ }^{91}$ Dengan kata lain, demokrasi dimaknai sebagai penghambaan dan pemihakan negara kepada kelompok mayoritas (beragama).

Dalam diskursus politik hukum, telah menjadi fakta yang tidak terbantahkan bahwasannya proses perumusan suatu regulasi acapkali penuh dengan muatan-muatan politis dan kepentingan tertentu..$^{92}$ Regulasi tidak muncul dari ruang hampa. Regulasi sejatinya merupakan produk politik. Sebagai produk politik, suatu regulasi sangat dipengaruhi oleh kekuatan-kekuatan politik besar/ mayoritas di lembaga politik di mana regulasi tersebut dirumuskan. Di samping kekuatan politik di lembaga politik, menurut Daniel S. Lev, proses pembentukan regulasi sangat ditentukan oleh konsepsi dan struktur politik yang berlaku di masyarakat. ${ }^{93}$ Karena itu, untuk memahami suatu regulasi, penting kiranya mempelajari struktur sosial dan kekuatan politik yang ada di masyarakat di samping juga mempelajari institusi politiknya. Hampir senada dengan Daniel S. Lev, Marzuki Wahid dan Rumadi mengatakan bahwa pembentukan hokum (regulasi) sangat dipengaruhi oleh visi politik pembuatnya, kultur masyarakat, kepentingan-kepentingan ekonomi, politik, sosial budaya, agama, dan sebagainya. ${ }^{94}$

${ }^{89}$ Ihsan Ali-Fauzi, dkk. Kontroversi Gereja, 37-38.

90 Ahmad Asroni, jurnal (Menyegel Rumah Tuhan: menakar kadar kemaslahatan peraturan bersama menteri agama dan menteri dalam negeri no. 9/2006 dan menteri no. 8/2006 dalam mereduksi konflikpendirian rumah ibadah di indonesia), 75.

91 , Moch. Nur Ichwan, "Menuju Governansi Humanis Agama: Refleksi Ulang Tahun Ke-64 Kementerian Agama". Makalah disampaikan dalam seminar HUT Kementerian Agama RI, Jakarta 21 Januari 2011. 5.

92 Moh. Mahfud MD, Politik Hukum di Indonesia (Jakarta: Rajawali Pers, 2009). 45.

${ }_{93}$ Daniel S. Lev, Hukum dan Politik di Indonesia: Kesinambungan dan Perubahan (Jakarta: LPES, 1990), XII.

94 Marzuki Wahid dan Rumadi, Fiqh Mazhab Negara: Kritik atas Politik Hukum Islam di Indonesia (Yogyakarta: LKiS, 2001), 41. 
Dalam konteks PBM No. 9/2006 dan No. 8/2006, tampak jelas bahwa nuansa kepentingan pemeluk agama mayoritas (Islam) sangat kental dalam regulasi tersebut. Hal ini tampak jelas dari isinya yang mengekang kelompok agama minoritas dalam beribadah dan mendirikan rumah ibadah. Selain dapat dilihat dari isinya, kentalnya nuansa kepentingan kelompok mayoritas (Islam) dalam PBM No. 9/2006 dan No. 8/2006 dapat ditengok dari latar belakang lahirnya regulasi tersebut yang merupakan revisi atas SKB Dua Menteri No.1/ BER/mdn-mag/1969.

\section{Pandangan Maqashid Al-Syari'ah Terhadap Perkembangan Regulasi Rumah Ibadat}

Perkembangan regulasi rumah ibadat secara detail dapat diketahui dari paparan pembahasan rumusan masalah pertama tersebut. Namun untuk memudahkan pembahasan rumusan masalah yang kedua, penulis akan mencoba mengambil garis besar dari pembahasan diatas.

SKB Dua Menteri Nomor 01/BER/mdn-mag/1969 tidak secara khusus mengatur tentang pendirian rumah ibadah. Peraturan tersebut secara umum mengatur tentang pengembangan dan penyiaran agama yang di dalamnya terkait pula dengan keberadaan rumah ibadah. Sementara PMB 9 dan 8 Tahun 2006 mengatur tiga hal, yaitu: pembinaan kerukunan umat beragama melalui pembentukan Forum Kerukunan Umat Beragama, prosedur pendirian rumah ibadat, dan penyelesaian bila terjadi konflik.

Selanjutnya penulis akan membahasnya menggunakan sudut pandang maqashid al-syari'ah. Analisis ini akan dimulai dari SKB Dua Menteri Nomor 01/BER/mdn-mag/1969 kemudian dilanjutkan dengan Sementara PMB 9 dan 8 Tahun 2006.

Keputusan bersama menteri agama dan menteri dalam negeri tersebut secara rinci berisi tentang pendirian rumah ibadat dan solusisolusi dari permasalahan rumah ibadat. Pasal empat berisi tiga ayat yakni berkenaan dengan keharusan rumah ibadat untuk mendapatkan izin dari pemerintah daerah, pertimbangan-pertimbangan yang harus diperhatikan oleh pemerintah daerah dalam memberikan izin. Pertimbanganpertimbangan tersebut adalah berupa pendapat Kepala Perwakilan Departemen Agama setempat, Planologi, kondisi dan keadaan setempat.

Sementara itu, PMB 9 dan 8 Tahun 2006 menjelaskan tentang landasan pendirian rumah ibadat harus berdasarkan pada keperluan nyata dan komposisi jumlah penduduk. Pendirian rumah ibadat tidak boleh dilaksanakan jika kerukunan, ketentraman dan ketertiban umum 
terusik dan terganggu. ${ }^{95}$ Oleh karena itu, pendirian rumah ibadah wajib memenuhi beberapa syarat, yaitu (1) Daftar nama dan Kartu Tanda Penduduk (KTP) 90 orang pengusul rumah ibadah yang disahkan oleh pejabat sesuai dengan batas wilayahsetempat, (2) KTP 60 orang warga setempat yang disahkan oleh kepala desa atau lurah, (3) Rekomendasi tertulis dari kantor Departemen Agama kabupaten atau kota setempat, (4) Rekomendasi dari FKUB kabupaten setempat. 96

Selanjutnya, pasal yang kelima juga mengandung tiga ayat dan masing-masing ayat tidak khusus berkaitan dengan rumah ibadat, akan tetapi lebih berkaitan dengan masalah keagamaan. Pasal kelima ini, membicarakan tentang tindakan pemerintah daerah dalam melerai konflik yang terjadi antar umat beragama, baik berhubungan dengan rumah ibadah atau tidak. Jika perselisihan itu sampai pada perbuatan yang melanggar hukum dan ada aturan khusus yang mengaturnya, maka pemerintah daerah harus menyerahkan kasus itu pada pihak yang berwajib.

Sementara itu, pada PMB 9 dan 8 Tahun 2006 menerangkan tentang izin sementara pemanfaatan bangunan gedung dan diatur dalam tiga pasal yakni pasal 18, 19 dan 20. pemanfaatan bangunan gedung sementara harus mendapat izin dari bupati atau walikota berupa surat keterangan pemberian izin sementara. Untuk mendapatkan surat keterangan itu, hendaknya para pemohon memenuhi dua syarat, yakni baik fungsi (harus mengacu pada peraturan perundang-undangan tentang bangunan gedung) dan pemeliharaan kerukunan umat beragama serta ketentraman dan ketertiban masyarakat. Instrumen yang dapat dilihat untuk memenuhi ketentraman dan ketertiban masyarakat adalah pertama: izin tertulis pemilik bangunan, kedua: rekomendasi tertulis lurah atau kepala desa, ketiga: pelaporan tertulis kepada FKUB kabupaten atau kota, keempat: pelaporan tertulis kepada kepala kantor departemen agama kabupaten atau kota. Jangka waktu izin sementara pemanfaatan bangunan gedung ini adalah maksimal dua tahun. ${ }^{97}$

Jika terjadi konflik di seputar pendirian rumah ibadah, maka pertama-tama diselesaikan melalui musyawarah mufakat bersama masyarakat setempat. Jika tidak tercapai, maka pemerintah kabupaten

95 Ibid.

96 peraturan bersama menteri agama dan menteri dalam negeri nomor: 9 dan nomor: 8 tahun 2006 (tentang pedoman pelaksanaan tugas kepala daerah/wakil kepala daerah dalam pemeliharaan kerukunan umat beragama, pemberdayaan forum kerukunan umat beragama, dan pendirian rumah ibadat).

97 Ibid.

$270 \mid$ JURNAL LISAN AL-HAL 
atau kota wajib memfasilitasi musyawarah secara adil dan netral. Manakala mediasi pemerintah kabupaten atau kota menemui jalan buntu, penyelesaian akhir ditetapkan melalui pengadilan setempat. ${ }^{9899}$

Perubahan SKB Dua Menteri Nomor 01/BER/mdn-mag/1969 yang hanya mengatur perizinan penyeselesaian masalah rumah ibadat secara umum kepada PMB 9 dan 8 Tahun 2006 yang mengatur lebih rinci, tidak lain hanyalah untuk mewujudkan kerukunan antar umat beragama. Tujuan ini di tuangkan dalam pertimbangan PMB 9 dan 8 Tahun 2006. Pemerintah berharap aturan ini menjadi indikator tercapainya tujuan yang mulia itu. Dalam islam, kerukunan dan perdamaian adalah nilai yang harus diperjuangkan dan diwujudkan. Sebab, dengan kedua hal ini stabilitas agama dan negara akan dapat terwujud serta kehidupan masyarakat akan terjamin.

Imam al-gozali mengatakan bahwa agama dan negara adalah dua saudara kembar, agama sebagai dasar sementara negara adalah penjaganya. Agama akan hilang tanpa negara dan negara akan hancur tanpa agama. ${ }^{100}$ Analogi ini sangat tepat untuk menunjukkan betapa butuhnya penerapan ajaran-ajaran agama dengan kendali negara. Pencurian akan meraja lela tanpa adanya kekuasaan negara untuk menghukumnya, perzinaan akan menjadi hal biasa tanpa keikutsertaan negara, dan lain sebagainya.

Akan tetapi, negara tidak bisa ikut campur dalam setiap urusan agama, karena hal itu akan menghilangkan kendali agama (wazi' diniy). Begitu juga dengan agama, ada hal-hal yang tidak dapat dan tidak sebaiknya diterobos oleh agama, seperti sistem negara. Agama tidak boleh ikut andil dalam urusan-urusan yang menjdi wewenang negara kecuali akan berdampak pada menghalalkan sesuatu yang haram dan mengharamkan sesuatu yang halal.

Nabi Muhammad bersabda: ${ }^{101}$

98 Ihsan Ali-Fauzi, dkk., Kontroversi Gereja, 37.

99 peraturan bersama menteri agama dan menteri dalam negeri nomor: 9 dan nomor: 8 tahun 2006 (tentang pedoman pelaksanaan tugas kepala daerah/wakil kepala daerah dalam pemeliharaan kerukunan umat beragama, pemberdayaan forum kerukunan umat beragama, dan pendirian rumah ibadat). Juz:1, 17.

100 Abu hamid muhammad bin muhammad al-gozali, ihya' ulum al-din, bairut,

101 Abu bakar bin abi syaibah, al-kitab al-mushannaf fi al-ahadist wa al-astar, arriyad 1409 H, Juz: 6, 543 .

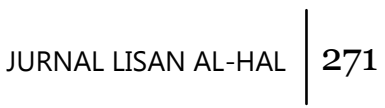




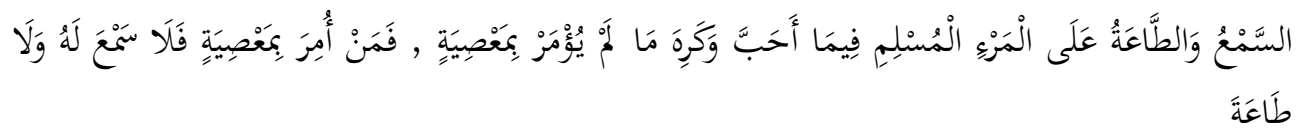

"Wajib bagi seorang muslim mendengar dan taat pada sesuatu yang diperintahkan baik ia sukai atau benci, selama ia tidak diperintahkan untuk melakukan maksiat. barang siapa yang diperintahkan untuk melakukan maksiat maka dia tidak boleh menaatinya"

Yang menjadi persoalan dalam masalah ini adalah apakah perubahan SKB Dua Menteri Nomor 01/BER/mdn-mag/1969 kepada PMB 9 dan 8 Tahun 2006 dapat mewujudkan kerukunan umat beragama atau tidak? Kalau memang mampu mewujudkan tujuan tersebut, lalu sampai tingkat mana peraturan tersebut mewujudkan kerukunan umat beragama? Untuk menjawab permasalahan ini, penulis akan menghadirkan kontra berkenaan dengan kedua peraturan tersebut. Setelah itu akan dilakukan analisis berkenaan dengan kelemahankelemahan dari kedua peraturan tersebut.

Kelemahan-kelemahan regulasi ini yaitu: Ketentuan tersebut tidak memiliki kekuatan hukum karena skb tidak termasuk dalam tata urutan peraturan perundangan Ri tap mpr no. III/MPR/2000. Ketentuan tersebut bertolak belakang bahkan menyeleweng dari pancasila (sumber hukum) dan undang-undang dasar 1945 (dasar hukum), walaupun dalam konsideras skb tersebut menyebut pasal 29 uud 1945. Penyebaran agama dan pelaksanaanibadah agama diturunkan atau direndahkan derajatnya menjadi kewenangan kepala daerah untuk mengaturnya, membumbing dan mengawasinya, sehingga penyebaran tersebut tidak mengganggu ketertiban umum (pasal 1,2,). Peranan pemerintah/kepala perwakilan departemen agama amat besar bahkan cendrung dapat mengintervensi khotbah di rumah-rumah ibadat sebagai suatu kegiatan sekuler yang mesti diawasi pemerintah demi terwujudnya stabilitas keamanan. Pendirian atau pembangunan rumah ibadat tidak dipahami sebagai pembangunan sebuah gedung yang tingkat kerawanannya amat tinggi sehingga memerlukan rekomendasi dari berbagai pihak (pasal 4). Munculnya interpretasi seolah pembangunan rumah ibadat itu sangat bergantung pada rekomendasi atau persetujuan maupun belas kasih seorang pejabat atau suatu kelompok golongan tertentu. Arogansi dari seorang pejabat atau kelompok mayoritas tertentu sangat mungkin terjadi dalam konteks ini. ${ }^{102}$

102 Tabloid Reformata Edisi 32 November 2005, yayasan pelayanan media antiokhia (YAPAMA).

$272 \mid$ JURNAL LISAN AL-HAL 
Dalam pandangan maqashid al-syari'ah, penulis menggunakan macam-macam maqashid secara hirarki sebagai alat analisis, yaitu dahruriyat, hajiyat dan tahsiniyat. Penulis juga akan menggunakan macam analisis yang lain sebagai pendukung guna memperoleh hasil yang lebih luas dan mendalam. Perkembangan regulasi rumah ibadat sangat dibutuhkan oleh para pemeluk agama, dengan harapan mereka memiliki kekuatan hukum untuk melindungi rumah ibadat mereka masing-masing. Mereka merindukan regulasi yang netral dan tidak berpihak kepada agama mayoritas, Dalam hal ini adalah agama islam. pembuatan regulasi biasanya tidak bisa lepas dari 'urf atau adat para pembuat kebijakan tersebut. Latar belakang mereka akan berpengaruh terhadap putusan atau kebijakan yang mereka ambil.

Kemudian, dari perkembangan regulasi di atas dapat dikelompokkan menjadi tiga bagian, sesuai dengan macam-macam maqashid. Pertama, dharuriyat, dharuriyat adalah tujuan Syāri' berupa kemaslahatan harus terpenuhi yang berakibat tegaknya agama dan kehidupan dunia. Yang masuk dalam maqashid ini adalah ada lima macam

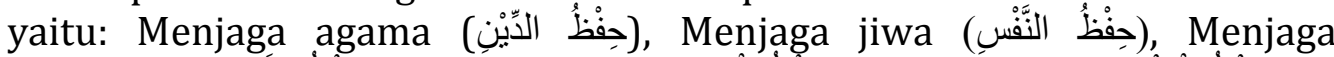

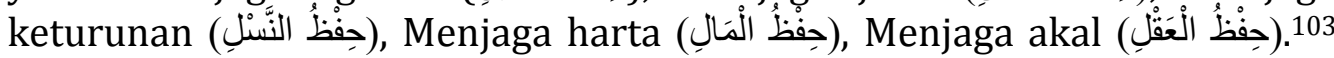
Kita mengatahui bahwa rumah ibadat adalah termasuk dalam kategori hifz al-din, karena tanpa rumah ibadah (syiar agama) agama akan hilang tanpa bekas. Dengan demikian, dapat disimpulkan bahwa yang masuk dalam kategori dharuriyat adalah pendirian rumah ibadat, terbentuknya FKUB. Minimal ada dua alasan kenapa penulis memasukkannya kedalam tahap dharuriyat, yang pertama, karena aturan yang mengatur pendirian rumah ibadah akan membuat stabilitas warga setempat. Yang kedua karena apabila pendirian rumah ibadah tidak diatur, maka para pemeluk agama akan dengan semena-mena membangun rumah ibadat tanpa memandang kemaslahatan bagi warga sekitar atau tidak, dengan demikian tata ruang daerah akan amburadul dan tidak teratur. Jika regulasi yang berkenaan dengan pendirian rumah ibadat dan pembentukan FKUB tidak ada, maka kerukunan antar umat beragama akan sulit tercapai. Dalam kasus ini kaidah yang paling tepat adalah:

$$
\text { وَلْلْوَسَائلِ أَحْكَامُ الْمَقَاصِدِ }
$$

"Sesuatu yang menjadi perantara memiliki hukum yang sama dengan tujuannya"104

103 Al-Syatibi, al-Muwafaqat fi Ushul al-Syari'ah (Beirut: Dar al-Kutub al-'Ilmiyah, 2005), Juz II, 7-8.

104 'Izzu ad-Din bin `Abd al-Salam, Qawaid al-Ahkam fi Masalih al-Anam (Kairo:

$$
\text { JURNAL LISAN AL-HAL } \mid 273
$$


Tujuan utama dari pembuatan regulasi rumah ibadat adalah terwujudnya kerukunan antar umat beragama. Hal ini dapat dicapai dengan adanya regulasi yang mengatur tentang pendirian rumah ibadat dan terbentuknya FKUB. Terbentuknya FKUB untuk menfasilitasi perwakilan dari masing-masing agama untuk mengutarakan tujuan atau keinginan mereka masing-masing. Dengan adanya dialog dan musyawarah antara perwakilan umat beragama akan lebih mudah mewujudkan kerukunan tersebut.

Kedua, hajiyat, Merupakan sesuatu yang dibutuhkan agar memperoleh kemaslahatan-kemaslahatan dan teraturnya urusan-urusan manusia dari aspek kebagusan. ${ }^{105}$ Melalui definisi ini kita dapat menentukan regulasi mana saja yang masuk dalam kategori ini. Menurut hemat penulis, yang masuk kategori ini adalah: Pengawasan dan Pelaporan dan Penyelesaian Perselisihan.

Alasan yang menjadi dasar keputusan ini adalah karena pengawasan dan pelaporan serta penyelesaian tidak sampai pada tataran inti dari tujuan tersebut. Namun tujuan tersebut tidak akan langgeng tanpa adanya pengawasan, pelaporan serta penyelasaian apabila terjadi konflik. Namun kadang pengawasan akan naik menjadi dharuriyat jika dalam kondisi konflik, dan penyelasaian konflik pun akan naik menjadi dharuriyat juga. Sebagaimana kaidah yang mengatakan:106

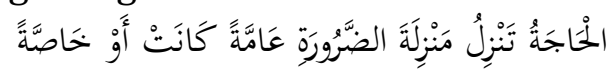

"Hajat itu kadang berada di posisi dharurat baik bersifat umum ataupun khusus"

Ketiga, tahsiniyat, tahsiniyat adalah sesuatu yang dibutuhkan agar kondisi dan tasharruf-tasharruf manusia menjadi lengkap, sempurna, dan paripurna. ${ }^{107}$ Definisi ini memberikan gambaran yang jelas bahwa hal-hal yang dimaksud atau dicakup oleh kategori ini adalah Rumah Ibadah Sementara, Ijin Sementara Pemanfaatan Gedung dan Mekanisme Peralihan.

Al-Syathibi merinci tahsiniyyat menjadi tiga bagian, antara lain: pertama, dalam hal ibadah, kedua, dalam hal adat, ketiga, dalam hal muamalat.108 Menurut hemat penulis, Rumah Ibadah Sementara, Ijin

Maktabah al-Kulliyyat al-Azhariyyah, 1994), Juz 1, 53.

105 Nu'man Jughaim. Thuruq al-Kasyfi 'an Maqāsid al-Syāri', 28.

106 Abdurrahman bin abu bakar jalaluddin al-suyuti, al-asybah wa al-nazda ir, dar al-kutub al-ilmiyah, 1990, 88.

107 Ibnu 'Asyur, Maqāsid al-Syarī'ah al-Islāmiyyah, 2.

108 Al-Syatibi, al-Muwafaqāt, Juz II, 10.

$274 \mid$ JURNAL LISAN AL-HAL 
Sementara Pemanfaatan Gedung, Mekanisme Peralihan dan Penutup masuk ke dalam pembagian yang kedua, yakni dalam hal adat. Ketiga regulasi rumah ibadah ini hanya sebagai pelengkap bagi regulasi-regulasi yang telah disebutkan dalam dharuriyat dan hajiyat. Sebab, ketiga regulasi ini hanyalah sebagai pelengkap dari regulasi-regulasi sebelumnya. Kalau pun tidak ditampilkan atau tidak dibuat, itu tidak akan menyulitkan para agamawan yang ingin melaksanakan ibadah mereka tanpa ada rumah ibadah sementara tersebut.

\section{E. Simpulan}

Perkembangan regulasi rumah ibadat dapat dikelompokkan mejadi dua model. Model pertama adalah merinci atau melengkapi regulasi sebelumnya, yakni ada pada item perizinan, pengawasan dan penyelesaian konflik. Model kedua adalah memunculkan regulasi baru yang tidak ada pada regulasi sebelumnya, yakni ada pada item adanya FKUB dan sumber dananya, rumah ibadah sementara, izin sementara pemanfaatan gedung, dan mekanisme peralihan.

Pandangan Maqashid Al-Syari'ah terhadap perkembangan regulasi rumah ibadat dapat dikategorikan ke dalam tiga golongan. kategori pertama adalah Dharuriyat, yakni: pendirian rumah ibadat dan terbentuknya FKUB. Kategori kedua adalah Hajiyat, tujuan utama dari pembuatan regulasi rumah ibadat adalah terwujudnya kerukunan umat beragama dibawah naungan FKUB yakni: Pengawasan, Pelaporan dan Penyelesaian konflik. Kategori ketiga adalah Tahsiniyat, seandainya regulasi ini tidak diberlakukan maka tidak akan mengganggu terwujudnya tujuan utama. Regulasi ini berupa: Rumah Ibadah Sementara, Ijin Sementara Pemanfaatan Gedung dan Mekanisme Peralihan rumah ibadat.

\section{DAFTAR PUSTAKA}

Abdullah, Sulaiman, Sumber Hukum Islam, Jakarta: Sinar Grafika, cet ke-1, 1995.

Abu Hamid al-Ghazali, Al-Mustashfâ min 'Ilmi al-Ushul Beirut: Dar al-Kotob al-'Ilmiyyah, TT.

Abu Hamid Muhammad bin Muhammad Al-Gozali, Ihya' Ulum Al-Din, bairut, Juz:1, TT.

Abu Zahrah, Muhammad, Ushul al-Fiqh, terj. Saefullah Ma'shum, et al., Ushul Fiqih Jakarta: Pustaka Firdaus, 2005.

Ali Fauzi, Ihsan dkk, Kontrofersi Gereja di Jakarta, Yogyakarta: CRCS UGM, 2011. 
al-Manzur, Ibn, Lisan al-'Arab al-Muhit Beirut: Dar al-Fikr, 1972.

al-Qardhawi, Yusuf, Madkhal li Dirasah al-Syari'ah al-Islamiyyah Kairo: Dar al-Syuruq, t.th.,.

Al-Syatibi, al-Muwafaqat fi Ushul al-Syari'ah Beirut: Dar al-Kutub al'Ilmiyah, 2005.

al-Zuhaily, Wahbah, Al-Fiqhu al-Islamy wa Adillatuhu t.t.: t.p., t.th., juz II, h. 1017.

Anhari, Masykur, Ushul Fiqh,Surabaya: Diantama, cet-1, 2008.

Asroni, Ahmad, Jurnal Menyegel Rumah Tuhan: menakar kadar kemaslahatan peraturan bersama menteri agama dan menteri dalam negeri no. 9/2006 dan menteri no. 8/2006 dalam mereduksi konflikpendirian rumah ibadah di indonesia.

Asry, M.Yusuf, Pendirian Rumah Ibadah Di Indonesia Pelaksanaan Peraturan Bersama Menteri Agama Dan Menteri Dalam Negeri No. 9 dan 8 tahun 2006, Kementerian Agama RI Badan Litbang Dan Diklat Puslitbang Kehidupan Keagamaan Jakarta, 2011.

Asry, Yusuf. Miskomunikasi dan Robohnya Sendi Harmoni Antar KristenIslam dalam Pembangunan Masjid Al-Munawar Narhornop Marsada, Kabupaten Tapanuli Utara. Jurnal Harmoni, 2014.

Auda, Jasser, Fiqh al-Maqāsid, Herndon: al-Ma'had al-'Ilmy li al-Fikri alIslamy, TT.

Auda, Jasser, Membumikan Hukum Islam Melalui Maqashid Syari'ah Bandung: Mizan Media Utama, TT.

Bakar, Abu bin Abi Syaibah, Al-Kitab Al-Mushannaf Fi Al-Ahadist Wa AlAstar, Ar-Riyad 1409.

Cholil, Suhadi Rumitnya Perizinan Rumah Ibadah, Suara Pembaruan, 31 Januari 2009.

Dachlan, Muh. Dinamika Pendirian Gereja Kristen Songka dan Gereja Toraja Jemaat Marannu di Kota Palopo. Jurnal SmaRT, 2015.

Dahlan, Abd. Rahman. Ushul Fiqh , Jakarta: Amzah, cet ke-2, 2011.

Daniel S. Lev, Hukum dan Politik di Indonesia: Kesinambungan dan Perubahan Jakarta: LPES, 1990.

Departemen Agama RI, Al-Hidayah: Al-Quran Tafsir Per Kata Tajwid Kode Angka Jakarta: Kalim, 2011.

Firdaus, Ushul Fiqh Metode Mengkaji dan Memahami Hukum Islam Secara Komperhensif, Jakarta: Zikrul Hakim, cet ke-1, 2004.

Fuady, Munir, Konsep Negara Demokrasi, Bandung : Refika Aditama, 2010.

Hakim,Abdul Aziz Negara Hukum dan Demokrasi Indonesia, Yogyakarta: Pustaka Pelajar, 2012.

http://nasional.news.viva.co.id/news/read/686836-detik-detik-

276 JURNAL LISAN AL-HAL 
pembakaran-gereja-di-aceh. 2017.

http://nasional.news.viva.co.id/news/read/686836-detik-detik-

pembakaran-gereja-di-aceh. 2017.

http://nasional.republika.co.id/berita/nasional/daerah/15/07/17/nrmpr

s-ini-kronologi-pembakaran-masjid-di-tolikara. 2017.

Human Rights Watch. Atas Nama Agama: Pelanggaran terhadap Minoritas Agama di Indonesia; 2013.

Ichwan, Moch. Nur, "Menuju Governansi Humanis Agama: Refleksi Ulang Tahun Ke- 64 Kementerian Agama". Makalah disampaikan dalam seminar HUT Kementerian Agama RI, Jakarta 21 Januari 2011.

Izzuddin bin 'Abdissalam, Qawaid al-Ahkam fi Masalih al-Anam. Kairo: Maktabah al-Kulliyyat al-Azhariyyah, 1994.

Jalaluddin Al-Suyuti, Abdurrahman bin Abu Bakar, Al-Asybah wa AlNazda ir, Dar Al-Kutub Al-Ilmiyah, 1990,

Keputusan Bersama Menteri Agama, dan Menteri Dalam Negeri Republik Indonesia, Bab IV Pendirian Rumah Ibadah Pasal 13. Pdf,

Kustini, dkk., Efektivitas Sosialisasi Peraturan Bersama Menteri Nomor. 9 dan 8 Tahun 2006 tentang Pedoman Pelaksanaan Tugas Kepala Daerah/Wakil Kepala Daerah dalam Pemeliharaan Kerukunan Umat Beragama, Pemberdayaan Forum Kerukunan Umat Beragama, dan Pendirian Rumah Ibadat Jakarta: Puslitbang Kehidupan Keagamaan, Badan Litbang dan Diklat Departemen Agama RI, 2009.

Mahfud MD, Moh, Politik Hukum di Indonesia Jakarta: Rajawali Pers, 2009.

Marzuki Wahid dan Rumadi, Fiqh Mazhab Negara: Kritik atas Politik Hukum Islam di Indonesia Yogyakarta: LKiS, 2001.

Prastowo, Andi, Menguasai Teknik-Teknik Koleksi Data Penelitian Kualitatif, Jogjakarta:Divapress, 2010.

Sunggono, Bambang, Metodologi Penelitian Hukum, Jakarta, Raja Grafindo Persada, 2001.

Syarifuddin, Amir. Ushul Fiqh, Jilid 2, Jakarta: Kencana, 2011.

Thahir Ibnu Asyur, Muhammad, Maqashid al-Syari'ah al-Islamiyah Tunisia: Dar al-Salam, 2006.

Thohir, Mudjahirin, Fundamentalisme Keagamaan dalam Perspektif Kebudayaan. Jurnal Analisa, XVII 02. 2010.

Undang-undang Dasar Tahun 1945 Pasal 28E Ayat: 1, Pasal 28I ayat: 1, Pasal 29 Ayat: 2, dan Pasal 22 Undang-undang UU Nomor 30 tahun 1999 tentang HAM.

Undang-Undang Republik Indonesia Nomor 39 Tahun 1999 tentang Hak Asasi Manusia,

Wahhab Khallaf, Abdul, Ilmu Ushul Fiqh, Jakarta: Dar al-Kutub al-Islamiyah,

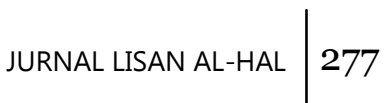


2010.

Wahhab Khallaf, Abdul, Kaidah-kaidah Hukum Islam, Jakarta: Raja Grafindo Persada, cet ke-6, 1996.

Yunus, Muhammad, Kamus Arab Indonesia Jakarta: Yayasan Penyelenggaraan Penerjemah dan Penafsir Alquran, 1973.

Zahro, Abu, Ushul Fiqh, Jakarta: pustaka firdaus, cet ke-14, 2011.

Zed, Mestika, Metode Penelitian Kepustakaan, Jakarta: Yayasan Obor Indonesia, 2008.

$278 \mid$ JURNAL LISAN AL-HAL 